\title{
The Compleat Jeffersonian: Justice Rehnquist and Federalism
}

\author{
Jeff Powell $†$
}

The Supreme Court under Chief Justice Warren Burger is widely perceived to be "drifting . . . a choir of most uncertain trumpets." It seems to lack both the powerful organizing principles and the commanding judicial personalities of the Warren Court. More and more frequently, the Burger Court has found itself badly split; individual cases often lead to a bewildering melange of separate opinions, partial dissents, and concurrences in the result. The Court's recurrent flipflops on doctrinal issues, ${ }^{2}$ and the not uncommon refusal of the Justices to accept as final a holding with which they disagree, ${ }^{3}$ point to wildly conflicting concepts of what they, and the Constitution, are about. The insistence of the individual Justices on presenting and adhering to their particular viewpoints suggests that they view judicial opinions not as attempts to fashion "decisions according to law" but rather as "opinions" in the everyday sense of that word.

This phenomenon-intense intellectual individualism destroying even the possibility of compromise or consensus-has not been confined to the Supreme Court. In Congress and elsewhere we see pro-choice and rightto-life lobbyists, proponents of affirmative action and opponents of busing, civil libertarians and the Moral Majority, and assorted other opposing groups squaring off for prolonged shouting matches in which both sides begin and end convinced of their own rectitude and of the other group's blindness, if not perversity. ${ }^{5}$ In legal circles this phenomenon frequently produces a sort of cynicism regarding constitutional law and quasi-constitutional statutes such as Title VII or the Sherman Act. People deeply and sincerely committed to their own positions in these areas nevertheless concede that their opinions are, at least in the sphere of legal discourse,

$\dagger$ J.D., Yale Law School, 1982. I wish to thank Professor Owen Fiss of Yale Law School for his advice and encouragement.

1. Kilpatrick, Why Justice O'Connor? 69 NaTION's BuS., October, 1981, at 20.

2. Compare Graham v. Richardson, 403 U.S. 365, 372 (1971) (alienage declared suspect classifcation for equal protection purposes) with Cabell v. Chavez-Salido, 102 S. Ct. 735, 738-40 (1982) (narrowing scope of Graham).

3. Note, for example, the refusal of Justices Brennan and Marshall to accept the majority's death penalty holding in Gregg v. Georgia, 428 U.S. 153 (1976). See, e.g., Rook v. North Carolina, 102 S. Ct. 1741 (1982) (Brennan and Marshall, JJ., dissenting from denial of cert.).

4. See C. BLACK, DECISION ACCORDING TO LAW (1981).

5. See A. MACINTYRE, AFTER VIRTUE 6-10 (1981). 
merely statements of policy preferences rather than legal arguments that seek to persuade others and are themselves open to criticism and correction on the basis of common principles. This attitude toward constitutional law reverses the old maxim that the American government is one of laws rather than of men; in effect it denies that the Constitution is law at all. In addition, by converting questions of constitutional law into purely partisan political disputes, it inverts de Tocqueville's remark that in America all questions of policy end up as questions of law.

This sea change in our legal culture indicates the dominance in constitutional discourse of emotivism - "[T]he doctrine that all evaluative judgments . . . are nothing but expressions of preference, expressions of attitude or feeling." From an emotivist standpoint evaluative judgments differ radically from factual judgments. The latter are true or false and can be evaluated by "rational criteria by means of which we may secure agreement as to what is true and what is false." Evaluative judgments, on the other hand, cannot be more than mere "expressions of preference." As a result, disagreement over an evaluative judgment can never be resolved by rational criteria. In the sphere of constitutional law, emotivism implies that there are no "neutral principles"' or universally accepted presuppositions that would enable us to conduct constitutional disputes as rational arguments. Even though the parties to such disputes may regard their positions as more than mere "expressions of attitude or feeling" in the context of their personal ethical or religious beliefs, both they and the judges who resolve the disputes are likely to perceive the arguments on both sides as "nothing but expressions of preference" in the sphere of legal discourse. The individualism currently gripping the Supeme Court is a strong indication that the Justices are operating within a framework of constitutional emotivism.

In such a "period of significant disarray in constitutional doctrine . . . [and] apparent disarray in the Court,"10 the subjects of this Article-federalism and Justice William Rehnquist-seem at first glance the most likely instruments for the refurbishing of doctrine and Court. Rehnquist frequently receives high marks from observers as one of the Court's most powerful intellects, ${ }^{11}$ and his authorship of many of the most impor-

6. Id. at 11 (emphasis added).

7. Id. at 11-12.

8. Wechsler, Toward Neutral Principles of Constitutional Law, 73 HARV. L. ReV. 1 (1959).

9. See A. MACINTYRE, supra note 5, at 235-36.

10. L. TRIBE, AMERICAN CONSTITUTIONAL LAW 1 (Supp. 1979).

11. Rehnquist has been called "the philosopher of this Court." Frank, The Burger Court-The First Ten Years, 43 LAW \& CONTEMP. PROBS. 101, 125 (Summer 1980). See also Shapiro, Mr. Justice Rehnquist: A Preliminary View, 90 HARV. L. REV. 293 (1976). Professor Shapiro's article, which discusses both the substance and the craftsmanship of Rehnquist's first five years as a Justice, is the starting point for any examination of Rehnquist the jurist. Shapiro's careful examination of Rehn- 
tant recent decisions of the Court ${ }^{12}$ testifies to his increasing influence on his colleagues. Furthermore, he has shown great concern over precisely the problem that is bedevilling the Gourt.

In a law review article published in 1976, Justice Rehnquist identified what is described here as emotivism in constitutional law as a pervasive threat to American legal and democratic values. ${ }^{13}$ Rehnquist used the term "the living Constitution" for an idea he found common in current constitutional discourse: that judges are free, in the name of the Constitution, to impose on the other branches of government "some other set of values [than] those which may be derived from the language and intent of the framers" of the Constitution. ${ }^{14}$ This idea assumes, Rehnquist wrote, that "there is [no] ascertainable content to the general phrases of the Constitution as they are written."15 Once this is accepted, he argued, constitutional argument becomes an exercise in pure emotivism:

Beyond the Constitution and the laws in our society, there simply is no basis other than the individual conscience of the citizen that may serve as a platform for the launching of moral judgments. There is no conceivable way in which I can logically demonstrate to you that the judgments of my conscience are superior to the judgments of your conscience, and vice versa. Many of us necessarily feel strongly and deeply about our own moral judgments, but they remain only personal moral judgments until in some way given the sanction of law. ${ }^{16}$

Justice Rehnquist's response to the reduction of constitutional discussion to a civil war of consciences is to reject the initial emotivist premise, and to argue that one can derive a determinate "set of values . . . from the language and intent of the framers" "by detached and objective" interpretation. ${ }^{17}$ The intent of the Framers can then serve as an objective stan-

quist's opinions led him to recognize in them "a kind of 'natural law' of states' rights." Id. at 302. Yet, since the full development of Rehnquist's federalism occurred after Shapiro's article was written, Shapiro failed to recognize federalism's role as the organizing principle in Rehnquist's work. Thus, he regarded National League of Cities v. Usery, 426 U.S. 833 (1976), as a departure from the principles Rehnquist claimed to be following rather than as the prototypical explication of the Justice's constitutional philosophy. See Shapiro, supra, at 306-07. Shapiro found three principles shaping Rehnquist's work: whenever possible, (1) conflicts between an individual and a government should be decided against the individual, (2) conflicts between states and the federal government should be decided against the federal government, and (3) federal jurisdiction should not be exercised. Id. at 294. As rough generalizations about the results of Rehnquist's jurisprudence, these principles are accurate. This Article argues, however, that Rehnquist's constitutional theory is more complex and less oriented toward particular political goals than Shapiro recognized.

12. E.g., Dames \& Moore v. Regan, 101 S. Ct. 2972 (1981) (Iranian assets case); Rostker v. Goldberg, 101 S. Ct. 2646 (1981) (draft registration case).

13. Rehnquist, The Notion of a Living Constitution, 54 TEX. L. REV. 693, 706 (1976).

14. Id. at 695 .

15. Id. at 698

16. Id. at 704 .

17. Id. at 695 . 
dard by which to measure constitutional arguments. Without such a standard, argues Rehnquist, judges will continue to function as "freewheeling" agents promoting their own notions of good policy rather than as "keepers of the covenant"18 originally entered into with the ratification of the Constitution. ${ }^{19}$

Drawing on an ancient theme in American political life closely associated with Thomas Jefferson, Rehnquist has argued that the constitutional first principle intended by the Framers was the maintenance of the federal system and of the dignity and autonomy of the states. In his view, solicitude for the values of federalism must therefore remain a primary goal of judicial decision-making.

This Article attempts to outline the theory of federalism that emerges from Justice Rehnquist's work on the Court. It first examines Rehnquist's articulation of the theory's basic themes in a series of decisions that center around his opinion for the Court in National League of Cities v. Usery. ${ }^{20}$ The Article then discusses Rehnquist's efforts to flesh out his theory of federalism in three significant areas: the relationship of federal power to the states' legislative authority, the relationship of the federal courts to the states' judicial and executive processes, and the restriction of Congress to its enumerated powers narrowly defined as the essential pre-condition for the states' autonomy. Finally, the Article argues that although Justice Rehnquist's work is consistent with the Jeffersonian theory of federalism, Rehnquist's attempt to transform this federalism into an objective constitutional first principle must fail because it cannot be established that the Framers intended to embody the theory in the Constitution.

\section{The Theory of Federalism}

The history of the United States is in large part the story of the American struggle to define the relationship between the states and the federal government. The Union under the Articles of Confederation was a loose alliance of quite separate states, in which "each State retain[ed] its sovereignty, freedom, and independence."21 The present Constitution was conceived and adopted as a result of the universal realization that under the Articles "the government of the United States is destitute of energy," "not adequate to the purpose of the Union." ${ }^{23}$ The resulting document

18. Id. at 698,699 .

19. Id. at 696 .

20. 426 U.S. 833 (1976).

21. ART. CONFED., art. II.

22. THE FEDERALIST No. 15, at 70 (Bantam Books ed. 1982) (A. Hamilton). Hamilton was one of the leading proponents of a strong national government.

23. Remarks of Thomas Tredwell, prominent opponent of the 1787 Constitution, quoted in G. WOOD, THE CREATION OF THE AMERICAN REPUBLIC 1776-1787, at 471 (1969). 
vested the federal government with greatly expanded powers and correspondingly constricted the autonomy of the states.

But the erection of this new constitutional structure did not end the struggle over the meaning of federalism. The vigorous nationalism of the Marshall Court provoked fear and suspicion among defenders of the states such as Thomas Jefferson. ${ }^{24}$ Andrew Jackson's firm assertion of national authority was countered by the nullification and concurrent majority theories of John C. Calhoun. ${ }^{25}$ Antislavery lawyers championed states rights against the invocation of federal law by slaveholders seeking fugitive slaves. ${ }^{26}$ In 1861, the seceding Southern states devised a federal union in which the balance of power would tilt permanently in favor of the states. ${ }^{27}$

But, just as the Civil War discredited the Confederacy's political experiment, the Reconstruction era's constitutional and statutory lawmaking repudiated the Confederacy's theory of federalism by greatly expanding the federal government's power to invade areas traditionally reserved to the states. ${ }^{28}$ Although Southern conservatives eventually succeeded in effectively nullifying federal guarantees of civil and political rights primarily intended to protect blacks, ${ }^{29}$ their final success took place in a period marked by increased federal judicial protection of property against state efforts to regulate capitalism. ${ }^{30}$ The due process rationale for this federal protection of economic conservativism was gradually extended to guaranteeing individual liberties such as freedom of speech against state interference. ${ }^{31}$ Despite the Supreme Court's acceptance of economic liberalism in the New Deal era, the expansion of federal power continued, finally re-

24. See Letter from Thomas Jefferson to Justice William Johnson (1823), reprinted in THE POLITICAL WRITINGS OF THOMAS JEFFERSON 146-49 (E. Dumbauld ed. 1955).

25. See R. REMINI, THE REVOLUTIONARY AGE OF ANDREW JAGKSON 82-100 (1976).

26. See Neuborne, The Myth of Parity, 90 HARV. L. REV. 1105, 1111-12 (1977).

27. See CONFEDERATE STATES CONST. art. I, § 2, cl. 5 (state legislature can impeach Confederate judges or officers resident and acting within the state). See also C.S. LEE, THE CONFEDERATE CONSTITUTIONS 150 (1963) (Confederate Constitution was ultimate constitutional expression of states' rights philosophy and state sovereignty concept in nineteenth-century America).

28. Sce U.S. CONST. amend. XIII (1865) (federal prohibition of slavery); amend. XIV (1868) (federal definition of state citizenship; federal guarantees against states of privileges and immunities of United States citizens, of due process, and of equal protection); amend. XV (1870) (federal prohibition of racial restrictions on voting). All three "Civil War Amendments" empowered Congress to enforce their provisions "by appropriate legislation." See also Civil Rights Act of 1866, 14 Stat. 27 (federal definition of United States citizenship; federal protection of basic civil rights); Force Act of 1871, 17 Stat. 13 (creating federal remedies for deprivation of federal rights under color of state law).

29. See W. GILLETTE, RETREAT FROM RECONSTRUCTION 1869-1879 (1979).

30. The final triumph of the Southern conservatives was the disfranchisement of blacks between 1890 and 1910. See C.V. WOODWARD, ORIGINS OF THE NEW SOUTH 321-49 (1971). In the same period, the federal courts began scrutinizing and invalidating state economic regulations under the authority of the Fourteenth Amendment's due process clause. The landmark decisions were Allgeyer v. Louisiana, 165 U.S. 578 (1897), and Lochner v. New York, 198 U.S. 45 (1905).

31. This process began with Gitlow v. New York, 268 U.S. 652 (1925). Although the Gitlow Court upheld a conviction under a state criminal anarchy statute it explicitly assumed that freedom of speech and press are protected against state impairment by the Fourteenth Amendment. Id. at 66. 
turning to the field of race relations from which it had begun, with opponents of the Supreme Court's school desegregation decisions invoking state sovereignty as a counter to the Court's assertion of federal authority. ${ }^{32}$

After the Supreme Court's timely repudiation of substantive due process, the struggle over the federal/state balance of power seemed largely resolved in favor of virtually plenary federal power. "[T] wisdom was that, since 1937, there have been no judicially enforceable limits on congressional power which derive from considerations of federalism. The sole protections for the states, it was said, were political." ${ }^{33}$ The Reagan Administration's recent proposals to "return" power to the states have dramatically demonstrated the potency of these political protections for state sovereignty. But even before the Executive Branch endorsed a refurbished federalism, the Supreme Court had opened the judicial door to a new era of "states' rights." In 1976, Rehnquist's opinion for the Court in National League of Cities v. Usery ${ }^{34}$ discredited the conventional wisdom and reintroduced state sovereignty as a functioning legal limitation on the federal legislative power. Although Usery engendered a storm of academic comment, ${ }^{35}$ it has not as yet been followed in other Supreme Court decisions. ${ }^{36}$ But while the case may be an aberration in the jurisprudence of the Court, it is central to Justice Rehnquist's view of constitutional law.

\section{A. The Emergence of the Theory}

Justice Rehnquist's understanding of state sovereignty first emerged with clarity the term before Usery, in Fry v. United States. ${ }^{37}$ Fry involved the application of the 1970 Economic Stabilization Act to state employees.

32. See C.V. Woodward, The Strange Career of Jim Crow 156-57 (2d rev. ed. 1966).

33. L. TRIBE, supra note 10, at 300 (1978). See also Wechsler, The Political Safeguards of Federalism: The Role of the States in the Composition and Selection of the National Government, 54 COLUM. L. REV. 543 (1954).

34. 426 U.S. 833 (1976).

35. E.g., Michaelman, States' Rights and States' Roles: Permutations of 'Sovereignty' in National League of Cities v. Usery, 86 YALE L.J. 1103 (1977); Monaghan, The Burger Court and "Our Federalism," 43 LAW \& CONTEMP. PROBS. 39 (1980); Tribe, Unraveling National League of Cities: The New Federalism and Affirmative Rights to Essential Government Services, 90 HARV. L. REV. 1065 (1977); Weinberg, The New Judicial Federalism, 29 STAN. L. REV. 1191 (1977).

36. The Supreme Court has rejected Usery-like arguments in Hodel v. Virginia Surface Mining \& Reclamation Ass'n, 452 U.S. 264 (1981), and Hodel v. Indiana, 452 U.S. 314 (1981) (Rehnquist, $\mathrm{J}$, concurring in judgment) (federal statute regulating surface coal mining does not violate state sovereignty by displacing state regulation). See also Transportation Union v. Long Island R.R. Co., 102 S. Ct. 1349 (1982) (operation of railroad is not a traditional state function protected by state sovereignty from federal regulation), and F.E.R.C. v. Mississippi, 102 S. Ct. 2126 (1982) (provisions of federal statute affecting state utility regulation not violative of state sovereignty). The Court has accepted for review a lower court ruling upholding a state challenge based on Usery to the application of the federal Age Discrimination in Employment Act of 1967 to state game wardens. See EEOG v. Wyoming, 514 F. Supp. 595 (D. Wyo. 1981), cert. granted, 102 S. Ct. 996 (1982).

37. 421 U.S. 542 (1975). 
The Pay Board established under the Act disallowed part of a pay increase voted by the Ohio legislature; the Ohio Supreme Court nonetheless ordered the full increase paid. The United States then sought an injunction to implement the Pay Board's ruling, which was granted by the Temporary Emergency Court of Appeals. The United States Supreme Court affirmed. Justice Marshall's opinion for the Court acknowledged that the Tenth Amendment "expressly declares the constitutional policy that Congress may not exercise power in a fashion that impairs the States' integrity or their ability to function effectively in a federal system," but stated that "we are convinced that the wage restriction regulations constituted no such drastic invasion of state sovereignty."38 The Gourt found Maryland v. Wirtz ${ }^{39}$ which upheld the application of the Fair Labor Standards Act to state-run hospitals and schools, to be a controlling precedent, and therefore upheld the Economic Stabilization Act as applied as a valid exercise of the congressional commerce power.

Justice Marshall's opinion was remarkable not for its pro-federal holding but for its apparent willingness to consider Ohio's Tenth Amendment argument. Earlier decisions had given much shorter shrift to invocations of state sovereignty. ${ }^{40}$ The majority's soft-spoken defense of federal authority nonetheless provoked one dissent on the merits-Justice Rehnquist's. ${ }^{41}$

Rehnquist rejected the Court's holding as contrary to "a concept of constitutional federalism which should . . . limit federal power under the Commerce Clause." ${ }^{42}$ Conceding that the Economic Stabilization Act was within the scope of the commerce clause, even as applied, Justice Rehnquist differentiated between "asserting an absence of congressional legislative authority" and "asserting an affirmative constitutional right." ${ }^{43} \mathrm{He}$ analogized Ohio's claim to an individual's invocation of a right guaranteed by the Bill of Rights, and distinguished an attack on a federal statute as exceeding the commerce clause's grant of power from an attack grounded on a claim that a constitutionally protected liberty is being infringed ${ }^{44}$ It

38. Id. at 547 n.7.

39. 392 U.S. 183 (1968).

40. E.g., California v. Taylor, 353 U.S. 553 (1957) (National Railroad Adjustment Board validly exercised jurisdiction over collective bargaining agreement between state-owned railroad and its employees); Case v. Bowles, 327 U.S. 92 (1946) (Emergency Price Control Act validly applied to state sales of timber); Helvering v. Gerhardt, 304 U.S. 405 (1938) (Congress can validly tax state Port Authority employees, state sovereignty notwithstanding); United States v. California, 297 U.S. 175, 185 (1936) ("The state can no more deny the power if its exercise has been authorized by Congress than can an individual.")

41. Justice Douglas found that the issue was moot due to the Act's expiration. 421 U.S. at 549 (Douglas, J., separate opinion).

42. Id. at 554 (Rehnquist, J., dissenting).

43. Id. at 553 .

44. Id. at 552-53. 
is "well established," Rehnquist argued, "[t]hat the latter claim is of greater force, and may succeed when the former will fail. . . ."4s

The "affirmative constitutional right" that the State of Ohio was asserting in Fry was, according to Justice Rehnquist, a right "as a State" to be free of economic regulation by Congress under its commerce power. ${ }^{46}$ Rehnquist distinguished the cases upholding Congress' power to tax state employees' salaries ${ }^{47}$ with the observation that the federal income tax statute "is addressed to the employee alone ..... Under the regulations which the Court upholds today, the State of Ohio is itself told that it may not pay more than specified amounts to its various employees." ${ }^{348}$ Despite the "rough similarites in practical effect" of the two laws-in both cases the employees' net pay is reduced below the gross amount set by the state- "the fact that the command of Congress operates directly upon the State in the latter situation is of significance in a system of constitutional federalism such as ours." ${ }^{\prime 49}$

Justice Rehnquist's opinion explicitly notes that the "state's right" he finds limiting Congress" power in Fry has, like state immunity from federal taxation, "no explicit constitutional source." Amendment that invalidates the Economic Stabilization Act, but rather a "right, inherent in [Ohio's] capacity as a State." In Rehnquist's view, the Tenth Amendment is simply an example

of the understanding of those who drafted and ratified the Constitution that the States were sovereign in many respects, and that although their legislative authority could be superseded by Congress in many areas where Congress was competent to act, Congress was nonetheless not free to deal with a State as if it were just another individual or business enterprise subject to regulation. ${ }^{52}$

Justice Rehnquist admitted that the federalism principle he discerns in the Constitution does not rule out all congressional activity upon the states. When a state engages in activity quite unlike its traditional activities, Congress can, in his view, regulate the state directly. ${ }^{53}$ Furthermore,

45. Id. at 553 .

46. Id. at 552 (emphasis in original).

47. See New York v. United States, 326 U.S. 572 (1946); Graves v. New York ex rel. O'Keefe, 306 U.S. 466 (1939); Helvering v. Gerhardt, 304 U.S. 405 (1938).

48. 421 U.S. at 554-55 n.1.

49. Id.

50. Id. at 554 .

51. Id. at 553 .

52. Id. at 557 .

53. Using this traditional-nontraditional state activities test, Justice Rehnquist distinguished United States v. California, 297 U.S. 175 (1936) (upholding application of Federal Safety Appliance Act to state). See 421 U.S. at 558 n.2. He indicated, however, that he thought Maryland v. Wirtz, 392 U.S. 183 (1968), the precedential basis for the majority's holding, was wrongly decided. See 421 
he left open the possibility that state sovereignty does not limit Congress: war power, or its enforcement power under the Civil War Amendments, in the same fashion that state sovereignty limits the commerce power. ${ }^{54}$

Justice Rehnquist's dissent in Fry thus outlined the basic contours of his theory of federalism: its origin not in the text of the Constitution but in "the intention of the Framers" 55 and its articulation as a doctrine of state sovereignty limiting congressional exercise of the commerce power. The opinion left unclear, however, both how the Framers' intent is to be discerned, and how far the states' "inherent" right to be free of direct congressional regulation extends. It was not until the next term, in $\mathrm{Na}$ tional League of Cities v. Usery, ${ }^{56}$ that Justice Rehnquist had an opportunity to begin to answer these questions.

\section{B. National League of Cities v. Usery: The Theory's Centerpiece}

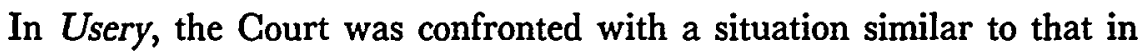
Fry. A 1974 amendment to the Fair Labor Standards Act extended the Act's minimum wage and maximum hour provisions to virtually all state and local government employees. Twenty states, the National League of Cities, the National Governors' Conference, and several local governments challenged the extension as an infringement of a constitutional right "running in favor of the States as States."257 A three judge district court dismissed the complaint on the basis of Maryland v. Wirtz. But despite the similarity of the petitioners' claim in Usery to the unsuccessful argument in $F r y$, on this occasion four other Justices accepted what was essentially the reasoning of Rehnquist's Fry dissent.

Writing for the Court, Justice Rehnquist paid cursory respect to the "plenary authority" the commerce clause grants to Congress. ${ }^{58} \mathrm{He}$ stated that "[ $t$ ]his Court has never doubted that there are limits upon the power of Congress to override state sovereignty, even when exercising its otherwise plenary powers to tax or to regulate commerce," ${ }^{\prime 59}$ an assertion that amazed the dissenters ${ }^{60}$ Rehnquist then reiterated his Fry distinction between asserting a lack of legislative authority for the Act and invoking an affirmative constitutional right contradictory to the Act. In doing so, he found a constitutionally significant difference between congressional regulation of individuals, which may have an ancillary impact on the states,

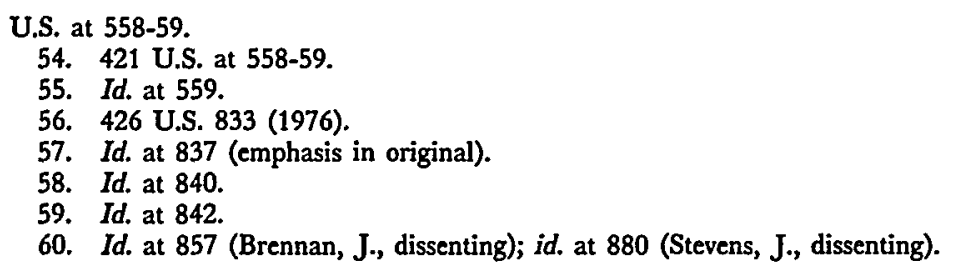


and the "exercise of congressional authority directed ... to the States as States." $11 \mathrm{He}$ then announced that the critical factor in determining whether a commerce clause regulation transgresses state sovereignty is whether the affected state functions are "essential to separate and independent existence." 62

Although the procedural posture of the case required the Court to take the appellants' allegations of severe interference with their governmental functions as true, ${ }^{63}$ Justice Rehnquist explicitly declined to base his conclusion on the specific impact of the Act on the states. ${ }^{64} \mathrm{He}$ discussed the possible effects of the 1974 amendment at some length, but in the end the question for Justice Rehnquist was not one of practical results but of constitutional principles.

[E]ven if we accept appellee's assessments concerning the impact of the amendments, their application will nonetheless significantly alter or displace the States' abilities to structure employer-employee relationships in such areas as fire prevention, police protection, sanitation, public health, and parks and recreation. . . it is functions such as these which governments are created to provide, services such as these which the States have traditionally afforded their citizens. If Gongress may withdraw from the States the authority to make those fundamental employment decisions upon which their systems for performance of these functions must rest, we think there would be little left of the States' "'separate and independent existence." "'65

The appellee Secretary of Labor's most potent contention was that $F_{r y}$ v. United States, and the decision on which it was based, Maryland v. Wirtz, precluded a decision for the appellants. But Justice Rehnquist gave the Secretary's argument short shrift. He distinguished Fry as being based both on the emergency character of the Economic Stabilization Act and on the fact that the Act did not displace state wage determinations but merely froze them at preexisting levels. ${ }^{66}$ His opinion also took the further step of overruling Wirtz, holding that Congress may not "force directly upon the States its choices as to how essential decisions regarding the conduct of integral governmental functions are to be made."67

61. Id. at 845 .

62. Id. The language is derived ultimately from Lane County v. Oregon, 74 U.S. (7 Wall.) 71,76 (1869).

63. The district court dismissed the complaint for failure to state a claim for which relief could be granted. 406 F. Supp. 826 (D.D.C. 1974).

64. 426 U.S. at 846.

65. Id. at 851 (quoting Coyle v. Oklahoma, 221 U.S. 559, 580 (1911)).

66. Id. at $852-53$.

67. Id. at 855 . 


\section{The Sources of the Theory of Federalism}

A year after Usery was decided, Justice Rehnquist had a chance to clarify his understanding of the sources of the state sovereignty doctrine in his dissent in Trimble v. Gordon. ${ }^{6}$ In Trimble, the Supreme Court held that an Illinois statute permitting illegitimate children to inherit by intestate succession only from their mothers violated the equal protection clause of the Fourteenth Amendment. Referring to history "too well known to warrant more than brief mention," Rehnquist wrote that

the Framers of the Constitution adopted a system of checks and balances conveniently lumped under the descriptive head of "federalism," whereby all power was originally presumed to reside in the people of the States who adopted the Constitution. The Constitution delegated some authority to the federal executive, some to the federal legislature, some to the federal judiciary, and reserved the remaining authority normally associated with sovereignty to the States and to the people in the States. ${ }^{69}$

He went on to assert that although the Civil War Amendments "sharply altered the balance of power between the Federal and State Governments," they did so only in specific, historically identifiable ways, and were not to be construed to affect radically "the original understanding at Philadelphia." 70

The most striking feature of Justice Rehnquist's use of history and structure is his minimalization of the constitutional effects of the Givil War. Although he recognizes that the Civil War amendments did work a change in federal/state relationships, he is concerned to limit the change to its narrowest justifiable scope. The general rule remains "the original understanding at Philadelphia"-state freedom from federal interference. Federal intrusion onto state turf can only be permitted on the basis of a textually demonstrable delegation of such power.

But history is not the only source of the state sovereignty doctrine for Justice Rehnquist. In his dissent in Nevada v. Hall, ${ }^{71}$ he indicated that federalism is a necessary component of constitutional law for structural as well as historical reasons. ${ }^{72}$ In that case Justice Rehnquist disagreed with the majority's conclusion that a state had no constitutional immunity from suit in another state's courts and no constitutional right to insist that the

68. 430 U.S. 762 (1977).

69. Id. at 777-78 (Rehnquist, J., dissenting).

70. Id. at 778 .

71. 440 U.S. 410,432 (1979).

72. Cf. C. BLACK, PERSPECTIVES IN CONSTITUTIONAL LAW 20-30, 39-43 (rev. ed. 1970) (implying a legal doctrine of federalism from structure and organization of Constitution). 
forum state disregard its own public policy on tort compensation in favor of the defendant's. He argued that the Court frequently has relied on

the implicit ordering of relationships within the federal system necessary to make the Constitution a workable governing charter and to give each provision within that document the full effect intended by the Framers. The tacit postulates yielded by that ordering are as much engrained in the fabric of the document as its express provisions, because without them the Constitution is denied force and often meaning . . . . The Court's literalism, therefore, cannot be dispositive here, and we must examine further the understanding of the Framers and the consequent doctrinal evolution of concepts of state sovereignty. ${ }^{73}$

Applying this methodology to the case, Rehnquist concluded that underlying the Eleventh Amendment is a general rule that states are not subject to suit absent their consent. ${ }^{74}$

\section{Federalism and State Sovereignty}

Justice Rehnquist uses the theory of federalism he described in Fry, Usery, Trimble, and Hall as his constitutional first principle. But Fry and Usery in particular stand not only for this first principle, but also for a specific elaboration of it, the doctrine of state sovereignty. That specific doctrine, unlike the broader theory, has fared poorly in succeeding cases. ${ }^{25}$

Only a few days after Usery was decided, the Supreme Court handed down its decision in Fitzpatrick v. Bitzer. ${ }^{76}$ The constitutional question in Fitzpatrick was whether, despite the Eleventh Amendment and the general principle of federalism, Congress had the power to authorize an award of money damages to a private individual against a state government found to have subjected that individual to employment discrimination. Justice Rehnquist's opinions in $F_{r y}$ and Usery had left open the question of the relationship of state sovereignty to the Fourteenth Amendment. Writing for a unanimous Court, Rehnquist confronted the issue, noting that the Amendment's provisions, on their face, run against the states. He therefore concluded that the Eleventh Amendment, and the principle of state sovereignty which it embodies, ". . . are necessarily limited by the enforcement provisions of $\S 5$ of the Fourteenth

73. Id. at 433-34 (Rehnquist, J., dissenting) (citations omitted).

74. Id. at 437.

75. In the Hodel cases, Transportation Union v. Long Island R.R. Co. and F.E.R.C. v. Mississippi, supra note 36 , the Supreme Court rejected arguments that state sovereignty shields state land use regulation, a state-owned railroad or a state utility commission from federal regulation.

76. 427 U.S. 445 (1976). 


\section{Amendment."'77}

Together, Usery and Fitzpatrick created a state sovereignty doctrine with fairly definite contours. Congress cannot regulate the states directly under its commerce power if the state activities affected are either traditional or essential to the states' functioning, unless (perhaps) the regulation is justified by a national emergency. On the other hand, Congress can directly "regulate" the states, even in an area protected by state sovereignty, when Congress acts to enforce the Fourteenth Amendment. But the precedents supporting this doctrine were never identified. Despite Justice Rehnquist's bold assertion in Usery that "[t]his Court has never doubted" the existence of state sovereignty limitations on congressional power, the wealth of precedent that Justice Brennan marshalled to support his dissent ${ }^{78}$ makes it obvious that the source of the state sovereignty is one of the doctrine's chief weaknesses. ${ }^{79}$

In his Fry opinion Justice Rehnquist had refused to rely on the Tenth Amendment as the constitutional provision creating a state sovereignty limitation on the commerce power, ${ }^{80}$ possibly because of the historical difficulties with so interpreting that Amendment. ${ }^{81}$ The $U$ sery opinion adopts the same position: The Tenth Amendment is "an express declaration" of the state sovereignty limitation, ${ }^{82}$ not its source. But in avoiding the historical pitfalls associated with linking his state sovereignty doctrine too closely to the Tenth Amendment, Justice Rehnquist left the doctrine floating in mid-air, without a visible constitutional foundation other than his theory of federalism. Rehnquist thereby increased the credibility of Justice Brennan's remark that "[m]y Brethren thus have today manufactured an abstraction without substance, founded neither in the words of the Constitution nor on precedent." ${ }^{\text {83 }}$

The scope as well as the source of the state sovereignty doctrine remain ambiguous. Usery did not define any particular state activities other than the power to determine state employees' wages and hours as essential to

77. Id. at 456.

78. See 426 U.S. at $857-60,863$ n.5 (Brennan, J., dissenting).

79. Justice Brennan's dissent emphasized the novelty, id. at 857 , and lack of support in the Constitution's text, id. at 858, or in the Court's decisions, id. at 858,867 , for the majority's position.

80. 421 U.S. at 557.

81. In his dissent in Usery, Justice Brennan referred to the weighty historical evidence against construing the Tenth Amendment as a limitation on powers expressly delegated to Congress, 426 U.S. at 861-63. That evidence includes the Marshall Court's decisions upholding an expansive construction of congressional power, e.g., M'Culloch v. Maryland, 17 U.S. (4 Wheat.) 316 (1819), as well as the opinions of distinguished early commentators like Justice Story, see, e.g., 2 J. STORY, COMMENTARIES ON THE CONSTITUTION 1907-08 (2d ed. Boston 1851).

82. 426 U.S. at 842 .

83. Id. at 860 . Later judicial opinions have tended to resolve this ambiguity in Usery by wedding the decision to the Tenth Amendment. E.g., Beame v. Friends of the Earth, 434 U.S. 1310, 1311 (1977) (Marshall, Circuit Justice) (Usery was interpretaton of Tenth Amendment); Peel v. Florida Dep't of Transp., 600 F.2d 1070, 1082 (5th Cir. 1979) (same). 
state autonomy. Dicta in the opinion noted that "fire prevention, police protection, sanitation, public health, and parks and recreation" are "typical" and "traditional" functions of the states. ${ }^{84}$ Many of these activities are carried out primarily by local governments acting under state authority rather than by the state government itself; hence, it would seem logical that the protections of state sovereignty should extend to these political subdivisions as well. Otherwise Congress could use its commerce power to achieve a goal impermissible under Usery - the direct regulation of traditional state functions-by regulating the local bodies that in fact perform most of these functions.

Justice Rehnquist has accepted this logic and would extend the doctrine to protect local governmental units, but most of the other justices have disagreed. In Community Communications Co. v. City of Boulder ${ }^{85}$ for example, a cable television operator sued a municipality enjoying home rule under the Colorado state constitution. ${ }^{86}$ The company alleged that a Boulder ordinance prohibiting it from expanding its business for a three month period while the city solicited competitors violated the Sherman Act. The Supreme Court held that the city was subject to Sherman Act. The Court also ruled that the political subdivision of a state cannot invoke the state action exemption to the Act recognized in Parker v. Brown ${ }^{87}$ unless it is implementing a clearly articulated state policy, which Boulder was not. ${ }^{88}$ Justice Rehnquist dissented, in an opinion joined by the Chief Justice and Justice O'Connor. He argued first that the majority had incorrectly analyzed the case in terms of an exemption from the Act, instead of in terms of preemption. ${ }^{89} \mathrm{He}$ went on to suggest that a preemption analysis required upholding the city's ordinance. Rehnquist termed "startling" the majority's conclusion that "our Federalism is in no way implicated when a municipal ordinance is invalidated," adding that "I see no principled basis to conclude, as does the Court, that municipal ordinances are more susceptible to invalidation under the Sherman Act than are state statutes." $"$ The Court's opinion, according to Rehnquist, frustrated the state's decision to permit certain communities to regulate business without resort to the state government, and was in effect the use of federal judicial power "to regulate the relationship between the States and their political

84. 426 U.S. at 851 .

85. 102 S. Ct. 835 (1982).

86. A municipality enjoying "home rule" status is entitled to enact a charter and ordinances governing local matters that within its territorial limits supersede the state's statutes. CoLO. CONST. art. $20 \S 6$.

87. 317 U.S. 341 (1943).

88. 102 S. Ct. at 841-43.

89. Id. at 845,849 .

90. Id. at 850 . 
subdivisions." ${ }^{11}$

\section{Federalism and State Legislative Autonomy}

Although Justice Rehnquist and Justise Brennan disagree violently over the meaning of federalism in constitutional law, Rehnquist would certainly agree with the observation in Brennan's Usery dissent that "the paradigm of sovereign action-action qua State" is the creation and enforcement of substantive state law. ${ }^{22}$ It follows from Justice Rehnquist's historical model of the Constitution - the imposition of a federal system on preexisting states possessing full governmental powers-that federal lawmaking is essentially interstitial. ${ }^{93}$ Even congressional legislation clearly enacted pursuant to a delegated power and directed to individuals rather than to the states is, in this model, to be construed narrowly in order to preserve the autonomy of the states' legislative and judicial power to make laws in areas not delegated (or exclusively delegated). This essential link between Justice Rehnquist's concern for federalism and his extraordinary deference to substantive state law is made most explicit in Rehnquist's opinion for the Court in Oregon ex rel. State Land Board v. Corvallis Sand \& Gravel Co.94

The question presented by Corvallis was whether a dispute over the ownership of lands underlying a navigable river was governed by federal common law or by Oregon state law. Despite the existence of old Supreme Court decisions indicating that federal law should be applied, the Court held that Oregon law governed the issue. In reaching this conclusion, Justice Rehnquist observed that "[u]nder our federal system, property ownership is not governed by a general federal law, but rather by the laws of the several States." ${ }^{\text {"9s }}$ Where a state seeks to apply its own law to resolve a dispute over property claimed by its own instrumentality, its right to do so is "substantially related to the constitutional sovereignty of the States." 196

The belief that a state has the right to have its law function without federal interference in the areas reserved to it pervades many other opinions and decisions by Justice Rehnquist. He joined, for example, in Justice Stewart's majority opinion in Board of Regents v. Roth, ${ }^{97}$ which stated that "[p]roperty interests, of course, are not created by the Consti-

91. Id. at 851 .

92. 426 U.S. at 875.

93. See P. BATOR, P. MISHKIN, D. Shapiro \& H. Wechsler, HaRT AND WechSLER'S The FEDERAL COURTS AND THE FEDERAL SYSTEM 470-71 (2d ed. 1973).

94. 429 U.S. 363 (1977).

95. Id. at 378 .

96. Id. at 381 .

97. 408 U.S. 564 (1972). 
tution. Rather, they are created and their dimensions are defined by existing rules or understandings that stem from an independent source such as state law . . . ."98 And Justice Rehnquist has taken an active role in applying the Roth theory to other cases. ${ }^{99}$

In Paul v. Davis, ${ }^{100}$ local Kentucky police had distributed to merchants a flyer that described a number of persons as known, active shoplifters. The plaintiff was included in the flyer even though he had never been convicted of shoplifting. The case seemed similar to Wisconsin v. Constantineau, ${ }^{101}$ which involved a state statute permitting local authorities or relatives to "post" the names of alcoholics who could then be refused the right to purchase liquor. The Constantineau Court held that the statute violated the appellee's right to due process. Despite the factual analogies, however, Justice Rehnquist reached the opposite conclusion in Paul v. Davis. He distinguished Constantineau by noting that the "posting" of the alcoholic's name

deprived the individual of a right previously held under state law-the right to purchase or obtain liquor in common with other residents. 'Posting,' therefore, significantly altered her status as a matter of state law, and it was that alteration of legal status which, combined with the injury resulting from the defamation, justified the invocation of procedural safeguards. ${ }^{102}$

In contrast, according to Rehnquist, the defamation by the police of the respondent in Paul v. Davis infringed no right created by Kentucky law. Therefore, the due process clause of the Fourtheenth Amendment, which applies when the state seeks "to remove or significantly alter" a legal right or status it has created, ${ }^{103}$ was inapplicable.

Paul v. Davis only indirectly involved the possibility of intrusion into the state's sovereign power to make law, ${ }^{104}$ while the Corvallis case involved direct displacement of the state's property law. Each decision, however, is a logical use of federalism both as a hermeneutical tool and as a substantive constitutional principle. In each Justice Rehnquist employs federalism as an instrument for supplying content to constitutional terms that lack definition, such as "liberty," "property," and "due process." In

98. Id. at $\mathbf{5 7 7 .}$

99. E.g., Parratt v. Taylor, 451 US. 527, 529 n.1 (1981) (Rehnquist, J.) (citing Roth for proposition that property interests are created by state law and not by federal Constitution).

100. 424 U.S. 693 (1976).

101. 400 U.S. 433 (1971).

102. 424 U.S. at 708-09 (emphasis added).

103. Id. at 711 .

104. A decision against the state, it could be argued, would have forced Kentucky to recognize a legal right to reputation that Kentucky had declined to enact into law. 
so doing he grounds his constitutional decisionmaking on something other than his own personal viewpoint, and thus can claim to circumvent the danger of emotivism. But in order for federalism to be a stable and objective interpretive device, state law must be accorded autonomy and freedom from federal interference. Thus both the substantive sovereignty principle and the hermeneutical theory require the Court, in Justice Rehnquist's view, to preserve state law against displacement.

Justice Rehnqiust has applied the reasoning of Paul v. Davis to cases in which the exclusivity of state property law, ${ }^{105}$ state corporation law ${ }^{106}$ and state family law, ${ }^{107}$ were at stake. But the most dramatic example of Justice Rehnquist's concern for the autonomy of the states' sovereign lawmaking powers is a case in which the substantive result of his position was arguably contrary to what many perceive to be his conservative sympathies.

PruneYard Shopping Center v. Robins ${ }^{108}$ involved an attempt by a group of California high school students to arouse opposition to a United Nations resolution against Zionism. The students chose a large, privately owned shopping center, the PruneYard, as the best forum for their pamphleteering and petition-circulating efforts. The shopping center's security personnel requested them to leave pursuant to a company policy. The students complied, but later sought an injunction in state court against being denied access to the PruneYard. The state superior court and court of appeals denied the injunction, but the California Supreme Court reversed, holding that the free speech and government petition provisions of the California Constitution protected the students' activity, subject to reasonable time, place, and manner regulations. ${ }^{109}$

On appeal to the United States Supreme Court, the decision was affirmed. Writing for the Court, Justice Rehnquist first dismissed the contention that Lloyd v. Tanner ${ }^{110}$ compelled reversal. Lloyd had rejected the argument that the federal Constitution forbade a privately owned shop-

105. See Board of Curators v. Horowitz, 435 U.S. 78, 82 (1978) (state law does not make attendance at state medical school a protected property right).

106. See First Nat'I Bank of Boston v. Bellotti, 435 U.S. 765, 822 (1978) (Rehnquist, J., dissenting) (state law grants corporations perpetual life and limited liability for economic purposes and denies them certain political rights unrelated to those purposes); $c f$. Citizens Against Rent Control/ Coalition for Fair Housing v. City of Berkeley, 102 S. Ct. 434, 439 (1981) (Rehnquist, J., concurring) (Bellotti dissent viewed limitation of political rights as quid pro quo for economic benefits offered by state law to corporations).

107. See Hisquierdo v. Hisquierdo, 439 U.S. 572, 591 (1979) (Stewart, J., joined by Rehnquist, J., dissenting) (state law governs division of retirement benefits received under 1974 Railroad Retirement Act upon dissolution of marriage); accord Santasky v. Kramer, 102 S. Ct. 1388, 1403 (1982) (Rehnquist, J., dissenting) (evidentiary standard in child neglect proceedings); McCarty v. McCarty, 453 U.S. 210, 236 (1981) (Rehnquist, J., dissenting) (military retirement benefits).

108. 447 U.S. 74 (1980).

109. 23 Cal. 3d 899, 592 P.2d 341, 153 Cal. Rptr. 854 (1979).

110. 407 U.S. 551 (1972). 
ping center from enforcing a handbilling prohibition on its premises. But Rehnquist pointed out that nothing in Lloyd itself limited "the authority of the State to exercise its police power or its sovereign right to adopt in its own Constitution individual liberties more expansive than those conferred by the Federal Constitution." "111

Faithful to the doctrine promulgated in Roth that it is state, not federal, law that creates the property rights protected by the Fourteenth Amendment, Justice Rehnquist found that the regulation of the PruneYard owner's property rights did not amount to a "taking" in the Fifth Amendment sense. He distinguished Kaiser Aetna v. United States, ${ }^{112}$ in which the Court struck down as a "taking" a federal attempt to compel free public use of a private marina that was connected to federally controlled navigable water, in part on the ground that the government interference with private property interests in PruneYard had created the property right in the first place. Unlike the federal government, the states possess "residual authority that enables [them] . . . to define 'property" in the first instance."113 This fact, and California's possession of a "sovereign right"114 to adopt and construe its own constitution, justified the application of an undemanding rational means test to the California court's action. ${ }^{115}$

The final contention of the PruneYard appellants was that requiring them to permit the students limited access to their property would force the appellants to appear to espouse the views of others, in violation of the First and Fourteenth Amendments. Justice Rehnquist pointed out that in cases cited by the PruneYard appellants, such as Wooley v. Maynard ${ }^{116}$ and Miami Herald Publishing Co. v. Tornillo, ${ }^{117}$ the state had prescribed the content of the messages forced on the appellants. In contrast, the opinions at issue in PruneYard were those of other private parties, and the shopping center owner remained free to disclaim connection with any views those parties expressed. ${ }^{118}$

PruneYard was a significant test of the depth of Justice Rehnquist's federalism convictions. If his theory of federalism were merely a surrogate or disguise for a simple conservative politics, ${ }^{119}$ this case would have been more happily resolved from his viewpoint by a reversal. The appellants'

111. 447 U.S. at 81 .

112. 444 U.S. 164 (1979).

113. 447 U.S. at 84 .

114. Id. at 81 .

115. Id. at 85 .

116. 430 U.S. 705 (1977) (holding unconstitutional New Hampshire requirement that motto "Live Free or Die" be displayed on automobile license plates).

117. 418 U.S. 241 (1974) (holding unconstitutional Florida requirement that newspapers publish political candidates' replies to editorial criticism free of charge).

118. 447 U.S. at 87-88.

119. See Shapiro, supra note 11, at 294. 
arguments were not without reason or analogical support from earlier decisions. Indeed, PruneYard seems quite similar to Kaiser Aetna and Wooley. In Kaiser Aetna, a government was also seeking to deprive private parties of the free and exclusive use of their own property, constructed with their funds. And in Wooley, as in PruneYard, the party upon whom a message was being forced was not in fact being forced affirmatively to say or appear to say anything and in any event was free to advertise his or her disagreement with the views being expressed. ${ }^{120}$ On the other hand, Rehnquist's federalism principle seems to lead inexorably to the result in PruneYard, for what greater intrusion on the states' sovereign authority to make law could there be than a federal decision forbidding them to ensure their citizens' personal liberties by constitutional guarantees?

III. "His Federalism:" Justice Rehnquist and Procedural Deference to State Courts

Justice Rehnquist's state sovereignty doctrine has not commanded universal or uniform support from his brethren. Although four other Justices joined his Usery opinion, subsequent decisions have failed to implement the broad constitutional principle Rehnquist attempted to establish in Usery. His fight to create a wide sphere of autonomy for state substantive law has had a similarly checkered career. But his call for enhanced federal deference to state procedure has met with greater support from other members of the Court.

Justice Rehnquist did not initiate the Court's expansion of its various techniques for relegating litigants to state courts, but he has played an increasingly important role in their elaboration. Before 1971, the Supreme Court recognized three distinct but related situations in which a federal court could decline to proceed even though it possessed jurisdiction: (1) Pullman abstention-where a case presenting a federal constitutional issue might be disposed of by state court determination of pertinent state law questions; ${ }^{121}$ (2) Burford abstention-where a federal decision would affect substantial state policy decisions or interfere unduly with the state's administration of its own laws; $;{ }^{122}$ and (3) situations in which difficult and unsettled questions of state law must be resolved. ${ }^{123}$ Justice Rehnquist has

120. See 430 U.S. at 722 (Rehnquist, J., dissenting).

121. See Railroad Comm'n v. Pullman Co., 312 U.S. 496 (1941).

122. See Burford v. Sun Oil Co., 319 U.S. 315 (1943).

123. In Meredith v. City of Winter Haven, 320 U.S. 228 (1943), the Court rejected the position that mere difficulty in deciding a state law question itself justifies abstention. The present scope and authoritativeness of Winter Haven, however, is questionable. See C. WRIGHT, HANDBOOK OF THE LAW OF FEDERAL COURTS 225-29 (3d ed. 1976); Field, The Abstention Doctrine Today, 125 U. PA. L. REV. 590 (1977). 
followed a middle road in cases involving these types of abstention, joining majorities spanning the Court's ideological spectrum in ordering abstention. ${ }^{124}$ And somewhat surprisingly, he has warned against automatic resort to the similar procedure of certification of state law questions to state supreme courts, despite the compatibility of that procedure with the "considerations of comity and cooperative federalism which are inherent in a federal system . . . ."125

Justice Rehnquist has taken much less of a backseat position, however, in the development of a different type of abstention-the doctrine stemming from the 1971 decisions in Younger v. Harris ${ }^{126}$ and its companion cases, ${ }^{127}$ and often referred to as "Our Federalism." federal court should abstain from enjoining a criminal prosecution that was begun in state court prior to the filing of the federal action, absent a showing that the injunction is necessary to avoid "immediate and irreparable injury" to the federal plaintiff or to counter bad faith on the state's part. ${ }^{129}$ Since joining the Supreme Court, Justice Rehnquist has argued for the abandonment of all four of the specific limitations to Younger present in the original opinion. Stripped of these specificities, Younger becomes a universal, constitutionalized doctrine. It is no longer a self-imposed limitation on the chancellor's discretion, but a necessary consequence of the Constitution's federalist first principles. To a remarkable extent, Rehnquist has carried a majority of the Court with him in his crusade to universalize Younger. He has authored two opinions for the Court holding the Younger principle applicable in situations in which no state court was involved. ${ }^{130}$ Several other Rehnquist opinions for the Court have applied Younger where a state civil action, not a criminal prosecution, was at stake. ${ }^{131} \mathrm{He}$ has participated significantly in the Court's erosion of the original Younger requirement that the state proceeding antedate the filing of the federal suit in order to be protected from federal interference. ${ }^{132}$ Only in his recently articulated desire to extend Younger

124. See Colorado River Water Conservation Dist. v. United States, 424 U.S. 800 (1976) (Stewart, Blackmun, \& Stevens, JJ., dissenting) (concurrent state court proceeding justified dismissal of federal action); Harris County Comm'rs' Court v. Moore, 420 U.S. 77 (1975) (Douglas, J., dissenting) (abstention appropriate when state court construction of state statute could moot federal constitutional challenge).

125. Lehman Bros. v. Schein, 416 U.S. 386, 393-94 (1974) (Rehnquist, J., concurring).

126. 401 U.S. 37 (1971).

127. See Byrne v. Karalexis, 401 U.S. 216 (1971); Dyson v. Stein, 401 US. 200 (1971); Perez v. Ledesma, 401 U.S. 82 (1971); Boyle v. Landry, 401 U.S. 77 (1971); Samuels v. Mackell, 401 U.S. 66 (1971). All these decisions were handed down with Younger on February 23, 1971.

128. See generally Fiss, Dombrowski, 86 YaLe L.J. 1103 (1977).

129. 401 U.S. at 54; see Samuels v. Mackell, 401 U.S. 69 (1971).

130. See Fair Assessment in Real Estate Ass'n v. McNary, 102 S. Ct. 177 (1981); Rizzo v. Goode, 423 U.S. 362 (1976).

131. See Juidice v. Vail, 430 U.S. 327 (1977); Huffman v. Pursue, Ltd., 420 U.S. 592 (1975).

132. See Doran v. Salem Inn, Inc., 422 U.S. 922 (1975); Hicks v. Miranda, 422 U.S. 332 (1975). 
to federal instrumentalities other than courts has Rehnquist's program thus far been rebuffed. ${ }^{133}$ Behind all of this judicial activism, Rehnquist's federalist presuppostion can be easily discerned: national interference with state activities is anomalous in a federal system and is to be judicially disfavored.

\section{A. The Principle of Comity Takes on a New Shape}

The original Younger decision was predicated on the need for comity between the federal and state courts. Regular federal interference with state criminal proceedings seemed to Justice Black to betray a distrust of state judges incompatible with the equal dignity due them under "Our Federalism." This quite traditional concern for comity between courts does not arise when the state courts are not involved, and Younger on its face seems inapplicable in such situations. Nevertheless, it was in just such a situation that the Supreme Court undertook a major expansion of the scope of the Younger doctrine. The decision, Rizzo v. Goode, ${ }^{134}$ was written by Justice Rehnquist. The federal district court in Rizzo ordered Philadelphia city and police officials to devise and submit for its approval a program for dealing with complaints about police misconduct. The court of appeals affirmed. Justice Rehnquist's opinion reversed the lower courts, based in part on the familiar "principles of . . f federalism": 135

Thus the principles of federalism which play such an important part in governing the relationship between federal courts and state governments, though initially expounded and perhaps entitled to their greatest weight in cases where it was sought to enjoin a criminal prosecution in progress, have not been limited either to that situation or indeed to a criminal proceeding itself. We think these principles likewise have applicability where injunctive relief is sought, not against the judicial branch of the state government, but against those in charge of an executive branch of an agency of state or local governments such as petitioners here. ${ }^{136}$

Rizzo thus represents a startling expansion of "Our Federalism." It completely cut loose the Younger doctrine from the considerations of comity between federal and state courts and from the traditional restraints on the exercise of equity powers in relation to criminal proceedings out of which it had been born only five years earlier.

133. See United Credit Bureau of America, Inc. v. NLRB, 102 S. Ct. 539 (1981) (mem.) (Rehnquist, J., dissenting).

134. 423 U.S. 362 (1976).

135. Id. at 379.

136. Id. at 380 . 
Rizzo's expansion of Younger was reconfirmed in Fair Assessment in Real Estate Association v. McNary, ${ }^{137}$ another opinion written by Justice Rehnquist. In McNary the Court affirmed lower court holdings that state taxpayers could not bring a damages action under the Force Act of $1871,{ }^{138}$ to redress the allegedly unconstitutional administration of the Missouri state tax system. The lower federal courts reached their decisions relying partially on the Tax Injunction Act, ${ }^{139}$ and partially on the principle of comity. ${ }^{140}$ Justice Rehnquist's opinion, however, did not even reach the question of the Act's application; instead, Rehnquist chose to rely entirely on the federalism principle that he found "reflect[ed]" in the Tax Injunction Act and on the principle of comity articulated in Younger: "This legislation, and the decisions of this Court which preceded it, reflect the fundamental principle of comity between federal courts and state governments that is essential to 'Our Federalism,' particularly in the area of state taxation." ${ }^{\prime 141}$

Rehnquist justified applying a doctrine originally based on traditional considerations of equity jurisprudence to an action at law for damages by distinguishing between the Younger rule proper and the "fundamental principle" it expresses. "Although these modern expressions of comity have been limited in their application to federal cases which seek to enjoin state judicial proceedings, a limitation which we do not abandon here, they illustrate the principles that bar petitioners' suit under $\S 1983 .{ }^{142}$ The Younger rule is thus limited to cases involving an attempt to enjoin state court proceedings, but since the Younger principle is subject to no such restraint, the "limitation" is effectively meaningless.

After Rizzo and McNary, the Younger doctrine can apparently function as a freewheeling judicial metaprinciple, available to trump virtually any federal equitable intervention into the affairs of state or local governments. This is a radical departure from the practice of the federal courts for many years, and indeed some of the Justices in Rizzo may not have intended for the decision to have such far-reaching effects. Read at face value, however, Rizzo is a perfectly logical extension of Justice Rehnquist's federalism doctrine. In a federal system consisting of sovereign states protected from direct federal regulation in all but a few narrrow areas, interference with state activities by the national judiciary is clearly unacceptable, except in the most unusual of situations. In a recent dissent from the Court's denial of certiorari in United Credit Bureau of America,

137. 102 S. Ct. 177 (1981).

138. 42 U.S.C. § 1983 (Supp. IV 1980).

139. 28 U.S.C. § 1341 (1976).

140. $102 \mathrm{~S}$. Ct. at 186.

141. Id. at 179.

142. Id. at 184. 
Inc. v. National Labor Relations Board ${ }^{143}$ Justice Rehnquist argued that the Younger principle should restrain not only federal courts but also federal agencies from interference with state processes. In United Credit Bureau, the NLRB had found that the petitioner had committed an unfair labor practice by filing a damages action in state court against a discharged employee who had filed a complaint with the Board. It ordered the petitioner to dismiss its state court action and pay the employee's legal expenses. The Fourth Circuit enforced the order and the Supreme Court refused to review the case. Justice Rehnquist's elaborate dissent on the merits states that "principles of federalism and comity should preclude the NLRB from [enjoining] . . a a state court damages action between two private entities ...." Once again his view was founded not on an explicit legal provision but on an underlying principle: "Federal interference with the States' judicial processes is no less contrary to the policies underlying [the Anti-Injunction Act, 28 U.S.G.] $\S 2283$ if that interference comes from a federal agency rather than from a federal court." ${ }^{\text {"144 }}$

\section{B. The Disappearance of the Limitation to Criminal Proceedings}

Rizzo and McNary not only extended Younger beyond its original concern with comity between courts, but also abandoned its limitation to criminal proceedings, which reflected Younger's roots in ancient equity doctrine. When the Court in later cases rested Younger solely on considerations of federalism, such a limitation no longer made sense. Its abandonment was presaged in Huffman v. Pursue, Ltd. ${ }^{145}$ In that case, the Court had to decide whether "Our Federalism" is relevant in the context, not of state criminal proceedings, but of civil actions in state courts in which state officials are seeking to enforce state laws. In Huffman, Ohio county officials had obtained a state court order declaring a theater that was exhibiting allegedly pornographic films a nuisance and closing it for a year. Without appealing the state judgment, the theater sought a federal injunction against enforcement of the state court's order. A three-judge district court, without considering Younger, granted the injunction. The Supreme Court reversed, in an opinion written by Justice Rehnquist, holding that the district court should have applied the Younger standard to decide whether an injunction should issue. ${ }^{146}$ The dissenters contended that Younger's application of the traditional doctrine of equity that the chancellor will not restrain a criminal prosecution was inapplicable to a civil proceeding. In answer, Justice Rehnquist stressed the primacy of federal-

143. See supra note 133.

144. Id. at 539, 541.

145. 420 U.S. 592 (1975).

146. Id. at 595-99, 611 . 
ism considerations in the Younger doctrine, considerations that mandated "standards of restraint that go well beyond those of private equity jurisprudence." 147 This primary federalism "component" to Younger applies "to a civil proceeding such as this quite as much as . . to a criminal proceeding." $148 \mathrm{He}$ also reasoned that the state proceeding in Huffman was "in important respects . . . more akin to a criminal prosecution than are most civil cases." 149 The federal court's intervention in such proceedings disrupts the "State's efforts to protect the very interests which underlie its criminal laws and to obtain compliance with precisely the standards which are embodied in its criminal laws."150

Huffman nonetheless purported to preserve the limitation of Younger to criminal and quasi-criminal proceedings. This limitation was formally abandoned in Juidice v. Vail. ${ }^{151}$ The appellees in Juidice had been held in contempt by New York courts for failing to satisfy judgments against them in several New York civil actions. A federal district court enjoined enforcement of the contempt proceedings.

Writing for the Court, Justice Rehnquist conceded that the district court's reading of the precedents was "not an implausible" one, but went on to state that "the principles of Younger and Huffman are not confined solely to the types of state actions which were sought to be enjoined in those cases." 152 After Juidice, the federal decision whether to intervene is no longer to depend on whether the state action is a criminal or quasicriminal proceeding, but is to be resolved so as to preserve the freedom of "the States and their institutions . . . to perform their separate functions in their separate ways." ${ }^{153}$ While the opinion claimed to reserve the question of Younger's general applicability to all civil litigation, ${ }^{154}$ it leaves no principled reason for declining to extend Younger to all state court proceedings. ${ }^{155}$

\section{G. The State Gets a Headstart in the Race to the Courthouse}

The Younger decision, by stressing which judicial proceeding com-

147. Id. at 603 .

148. Id. at 604 .

149. Id.

150. Id. at 605 (footnote omitted).

151. 430 U.S. 327 (1977).

152. Id. at 334 .

153. Id. (citing Hufiman v. Pursue, Ltd., 420 U.S. 592, 601 (1975), which, in turn, quoted Younger v. Harris, 401 U.S. 37, 44 (1971)).

154. 430 U.S. at 336 n.13.

155. Justice Brennan wrote, "I suspect that the purported disclaimer . . . is tongue in cheek" and a cover "for the ultimate goal of denying \$ 1983 plaintiffs the federal forum in any case, civil or criminal, when a pending state proceeding may hear the federal plaintiff's federal claims." Id. at 344 45 \& n.* (Brennan, J., dissenting). See Moore v. Sims, 442 U.S. 415 (1979) (Younger abstention appropriate when state proceeding involves custody of children). 
mences first-the federal suit or the state prosecution-seemed to invite a "race to the courthouse." Since 1971 the Court has labored to reduce this element in the Younger doctrine by making it increasingly easy for the state to win the "race." In Hicks v. Miranda" ${ }^{156}$ Justice Rehnquist joined Justice White's opinion for the Court, which held that Younger applies "where state criminal proceedings are begun against the federal plaintiffs after the federal complaint is filed but before any proceedings of substance on the merits have taken place in the federal court."157 Four Justices dissented, attacking the holding as a radical skewing of the balances established in Younger between competing state and federal interests in favor of the state officials. ${ }^{158}$

Justice Rehnquist reaffirmed the principle established in Hicks in his majority opinion for the Court in Doran v. Salem Inn, Inc. ${ }^{159}$ The appellees were three corporations operating bars with topless dancers in North Hempstead, New York. After the town enacted an ordinance making this illegal, the three corporations brought a federal action seeking a declaration of the ordinance's unconstitutionality. After the federal court denied their request for a temporary restraining order, one bar reintroduced topless dancing and was served with criminal summonses by town officials. Thereafter, the district court found the ordinance unconstitutional and enjoined any proceedings under it. The Court of Appeals for the Second Circuit affirmed.

Justice Rehnquist's opinion rejected the appeals court's rationale-the need to avoid conflicting outcomes and conserve judicial energy-as insufficient to overcome "the claims of federalism."160 With respect to the bar that reintroduced topless dancing, he reasoned that "[w]hen the criminal summonses [were] issued . . . the federal litigation was in an embryonic stage and no contested matter had been decided."161 In such circumstances, Younger and Hicks v. Miranda barred both injunctive and declaratory relief. The Court went on to affirm the granting of declaratory and temporary injunctive relief to the other. two respondents.

\section{The Eleventh Amendment}

The Constitution does, of course, contain an explicit restriction on the application of federal power to the states, in the Eleventh Amendment. In his Fry opinion, Justice Rehnquist noted that Eleventh Amendment "re-

156. 422 U.S. 332 (1975).

157. See id. at 349 .

158. Id. at 357 (Stewart, J., dissenting).

159. 422 U.S. 922 (1975).

160. Id. at 928 .

161. Id. at 929 . 
flects" the principles of federalism that bind and inform constitutional interpretation. ${ }^{162}$ As in his treatment of the Tenth Amendment, however, Rehnquist does not derive these principles from an exegesis of the Amendment's language, and so he follows a rather sinuous path in the Court's Eleventh Amendment cases. While in several decisions he has joined a majority on the Court in rejecting Eleventh Amendment claims, he has not done so in every case. He joined the Court's opinion in the Missouri Public Health \& Welfare Employees Case, which held that congressional exercise of the commerce power against the states lifts the latter's Eleventh Amendment immunity as long as there is "clear language that the constitutional immunity had been swept away." $163 \mathrm{He}$ also joined in the holding of Scheuer v. Rhodes ${ }^{164}$ that the Eleventh Amendment does not bar an action for damages against state officials under the $1871 \mathrm{Ku}$ Klux Klan Act. Rehnquist wrote the opinion of the Court in Fitzpatrick v. Bitzer, which held that the Eleventh Amendment and its underlying state sovereignty rationale "are necessarily limited by the enforcement provisions of $\S 5$ of the Fourteenth Amendment." "165 Similarly, in Milliken v. Bradley ${ }^{166}$ he agreed with the decision that, notwithstanding the Eleventh Amendment, a district court could order state-funded remedial educational programs for children found to have been subjected to past acts of de jure segregation.

In Edelman v. Jordan, ${ }^{167}$ however, Justice Rehnquist wrote an opinion for the Court upholding an Eleventh Amendment claim. The Edelman plaintiffs successfully argued in district court that Illinois officials administering an aid program with joint federal-state funding were violating federal regulatory requirements. The court ordered the defendants to abide by the federal regulations and to pay all benefits wrongfully withheld after the promulgation of the regulations. The Seventh Circuit affirmed, rejecting the officials' claim that the Eleventh Amendment barred the award of retroactive benefits. Justice Rehnquist's opinion reviewed the history of the Eleventh Amendment, its extension in Hans v. Louisiana, ${ }^{168}$ and the exception for suits seeking prospective relief created in Ex parte Young. ${ }^{169} \mathrm{He}$ concluded that "[t]he funds to satisfy the award in this case must inevitably come from the general revenues of the State of Illinois,

162. 421 U.S. 542, 556-57 (1975) (Rehnquist, J., dissenting).

163. Employees v. Missouri Dep't of Public Health \& Welfare, 411 U.S. 279, 285 (1973).

164. 416 U.S. 232 (1974).

165. 427 U.S. 445,456 (1976).

166. 433 U.S. 267 (1977).

167. 415 U.S. 651 (1974).

168. 134 U.S. 1 (1890) (federal judicial power does not extend to suit directly against state by one of its own citizens absent that state's consent).

169. 209 U.S. 123 (1908). 
and thus the award resembles far more closely the monetary award against the State itself [prohibited by the Amendment and by Hans] . . . than it does the prospective. injunctive relief awarded in Ex Parte Young."170

On remand, the district court ordered the state officials to send each member of the plaintiffs' class a notice stating that he or she had been illegally denied benefits. The appeals court reversed, holding that the specific form of notice required in the district court's order was barred by the Eleventh Amendment, but that on remand the lower court could order the officials to send a simple explanatory note concerning state procedures available. When the case once again came up for Supreme Court review, as Quern v. Jordan, Justice Rehnquist again wrote for the Court, which upheld the appeals court's order as "ancillary to the prospective relief already ordered," and thus within the Ex Parte Young exception.

\section{E. Conclusion}

Justice Rehnquist's role in the evolution of the Younger principle of "Our Federalism" and in the revival of the Eleventh Amendment has been central both to the Court's decisions and to his own development of the meaning of federalism as a constitutional first principle. Younger, according to the interpretation Rehnquist gave it in Rizzo and McNary, is an exact parallel to Usery. Just as the state sovereignty invoked in Usery bars federal legislative interference with state legislative decisions, so Younger, Rizzo, and McNary bar federal judicial interference with state judicial or executive process. Similarly, Edelman v. Jordan prohibits the federal courts from vindicating federal statutory rights by making demands on the state exchequer except pursuant to congressional enforcement of the Fourteenth Amendment. Taken to their logical extremes, these doctrines would create an almost impenetrable sphere of state autonomy, open to federal interference at only two points. One is the Supreme Court's appellate jurisdiction over state court decisions involving federal questions. The other is Congress' enforcement power under the Civil War Amendments. Justice Rehnquist has indicated a desire to interpret the Court's jurisdiction narrowly, ${ }^{171}$ but has concentrated his efforts on attempting to patch up the Fourteenth Amendment chink in the states' federalism armor.

The most potent statutory intrusion into state autonomy under the Civil War Amendments is the Force Act of 1871, 42 U.S.C. $§ 1983$. Although

170. 415 U.S. at 665.

171. See Philadelphia Newspapers, Inc. v. Jerome, 434 U.S. 241, 244 (1978) (Rehnquist, J., dissenting) (when state court judgment arguably rests on both state and federal grounds, Supreme Court should not take jurisdiction unless it is obvious that decision was based on federal law). 
the Younger line of cases has severely cut back on the scope of section 1983 , it has not vitiated the statute completely, due to the continuing validity of Monroe v. Pape's holding that an individual seeking federal protection under the statute need not seek state judicial vindication of his or her federal rights before going into federal court. ${ }^{172}$ As might be expected, Justice Rehnquist has hinted strongly that he would overrule Monroe v. Pape and require aggrieved persons to exhaust their state remedies before invoking the 1871 Act. ${ }^{173}$

This negative attitude toward federal protection of individual liberties flows quite naturally from Rehnquist's federalism and does not necessarily stem from an antipathy toward civil and political rights in general. Its perspective is that of Barron v. Mayor and City Council of Baltimore : ${ }^{174}$ it is the states, and not the federal government, which are the source and should be the protectors of individual liberties. For Rehnquist, the section 1983 exception to this general rule is anomalous and should be construed as narrowly as possible. ${ }^{175}$ In his view, it is an "obvious precept" that litigants "seeking protection of federal rights in federal courts should be remitted to their state remedies if their federal rights will not thereby be lost.".176

The flip side of Justice Rehnquist's belief in the autonomy of state procedure is his belief that state courts should be in a position of complete parity with federal courts. Rehnquist thus has enthusiastically endorsed the assumption at least nominally shared by all the Justices that state courts are equal to federal courts in their ability and willingness to vindicate federal rights. ${ }^{177}$ In General Atomic Co. v. Felter ${ }^{178}$ he went beyond

172. 365 U.S. 167 (1961).

173. In dissenting from the Court's denial of certiorari in City of Columbus v. Leonard, 443 U.S. 905 (1979), Justice Rehnquist suggested that "the time may now be ripe for a reconsideration of the Court's conclusion in Monroe . . a to exhaustion of state remedies." Id. at 910-11. Justice Rehnquist's willingness to restrict the availability of $\S 1983$ is, logically, paralleled by opposition to expanding the statute's scope. Thus, he joined Justice Powell's dissent in Maine v. Thiboutot, 448 U.S. 1 (1980). The Thiboutot majority held that $\$ 1983$ encompasses claims based on purely statutory federal rights. Powell's dissent argued, in true Rehnquistian spirit, that the holding "creates a major new intrustion into state sovereignty under our federal system." Id. at 33.

174. 32 U.S (7 Pet.) 243 (1833) (first eight amendments inapplicable to states).

175. See Fair Assessment in Real Estate Ass'n v. MeNary, 102 S. Ct. 177 (1981).

176. Id. at 186 n.8. Justice Rehnquist's desire to channel litigants into state courts is based on his constitutional commitment to the states as the primary loci of governmental power and authority, not on empirical assertions about the competence or zeal of state judges. The argument that state judges on the whole are not as solicitous of federal rights in practice, set forth in Neuborne, supra note 26, misses the point as far as Rehnquist is concerned. To the Justice the proper question to ask is not "How can federally guaranteed rights best be protected?" but rather "In a federal system in which the states are primary and the central government secondary, which government's courts should ordinarily exercise jurisdiction?"

177. Moore v. Sims, 442 U.S. 415, 430 (1979); Huffman v. Pursue, Ltd., 420 U.S. 592, 610-11 (1975).

178. 434 U.S. 12 (1977). 
any of his colleagues in suggesting that state courts should be able to exercise the same injunctive authority granted to the federal courts by the Anti-Injunction Act, ${ }^{179}$ "where necessary in aid of [their] jurisdiction, or to protect or effectuate [their] judgments." ${ }^{\prime 180}$ The case arose out of the manyfold increase in the market price of uranium in the early 1970's. United Nuclear Corp. (UNC) was under contract to supply petitioner GAC with uranium; when rising costs in prices rendered the contract unremunerative UNC stopped delivery and in August 1975 filed a complaint in a New Mexico district court seeking a declaratory judgment releasing it from the contract. On March 15, 1976, the state court granted UNC an ex parte temporary order restraining GAC from suing UNG, and on April 2 issued a preliminary injunction to that effect, excepting two actions previously filed in a federal court in New Mexico. GAC asked the New Mexico Supreme Court to stay the injunction by writ, which the high court did pending oral argument, after which it quashed the writ. On appeal, the United States Supreme Court vacated the judgment and remanded the case so that the New Mexico Supreme Court could decide whether its decision was based on federal or state grounds. The state court held that the injunction was within the state district court's inherent equity powers and did not contravene the federal Constitution.

The United States Supreme Court, citing Donovan v. Dallas, ${ }^{181}$ summarily reversed. Justice Rehnquist was the sole dissenter. Rehnquist suggested a reexamination of Donovan's holding that state courts lack the power to restrain federal proceedings in actions in personam. According to Rehnquist, Donovan was based on the general rule of federalist comity that state and federal courts should not interfere with one another's proceedings. ${ }^{182}$ But "such a general rule of parity implies that, where a federal district court has power to enjoin the institution of proceedings in state court, a state court must have a similar power to forbid the initiation of vexatious litigation in federal court." 183

General Atomic Co. is, in a sense, the high water mark of Justice Rehnquist's procedural federalism. Starting from the generally accepted

179. 28 U.S.C. $\$ 2283(1976)$.

180. General Atomic Co. v. Felter, 434 U.S. 12, 20 (1977) (Rehnquist, J., dissenting) (quoting 28 U.S.C. $§ 2283$ (1976)).

181. 377 U.S. 408 (1964).

182. 434 U.S. at 19-20 (Rehnquist, J., dissenting).

183. Id. at 20. The state district court persisted in acting as though Justice Rehnquist's dissent had been the opinion of the Court. After remand, GAC filed a request with the American Arbitration Association for arbitration under federal law, and requested the state court to stay its proceedings. UNC replied by moving that the court enjoin the arbitration proceedings. The district court denied the motion to stay and granted the injunction. GAC then filed a motion in the United States Supreme Court for leave to file a petition for a writ of mandamus to compel the state court to abide by the Supreme Court's earlier ruling. The motion was summarily granted without dissent. See 436 U.S. 493 (1978). 
principle that federal-state comity may at times restrain federal courts from interfering in state court proceedings, Justice Rehnquist has come to the extraordinary conclusion that federalism requires federal courts to abstain from conducting their own proceedings when a state court interferes.

\section{Justice Rehnquist and Limits on Federal Power}

John Taylor, one of the great theoreticians of Jeffersonian republicanism, wrote in 1823 that

Communities possessed of sufficient knowledge to discriminate between liberty and slavery have uniformly labored to invest governments with a portion of power sufficient to secure social happiness, but insufficient for its destruction. ${ }^{184}$

A characteristic American response to the conundrum posed in the quotation above has been to emphasize state sovereignty. This solution fell into desuetude after the 1937 "constitutional revolution," and Justice Rehnquist has devoted much energy to reviving it. But there is another, equally traditional device for restricting a potentially oppressive federal authority-the doctrine of enumerated powers. Another nineteenth century Jeffersonian asked "What, then, is the Government of the United States? . . . Unlike the governments of the States, which have been instituted to secure generally the unalienable rights of man, it has only the enumerated objects and is restrained from passing beyond them by the express reservation of all undelegated functions." ${ }^{185}$ Expressed in the Tenth Amendment, ${ }^{186}$ this concept of the federal government has played an important role in American history. Like its federalism counterpart, however, the doctrine of a limited federal government had lost most of its vitality by the time William Rehnquist was appointed to the Supreme Court. ${ }^{187}$

Justice Rehnquist's work on the Court indicates that he has undertaken

184. J. TAYLOR, NEW VIEWS OF THE CONSTITUTION OF THE UNITED STATES (1823), quoted in 5 THE ANNALS OF AMERICA 88-89 (1968).

185. 2 J. DAVIS, RISE AND FALl OF THE CONFEDERATE GOVERNMENT 453 (1881).

186. "The powers not delegated to the United States by the Constitution, nor prohibited by it to the States, are reserved to the States respectively, or to the people." U.S. CONST. amend. X.

187. Professor Martin Diamond wrote:

For decades the limiting doctrine of delegated and enumerated powers has been eroded, and the scope of national government had been vastly expanded. . . . [T] preserve the federalism in the American compound remain concerned to limit the growth of national government relative to the states, as one indispensable support for that federalism. To this end, it is especially necessary to restore the moral and intellectual bona fides of the constitutional doctrine of enumerated powers as a crucial resource for limiting that growth.

Diamond, The Federalist on Federalism: "Neither a National Nor a Federal Constitution, But a Composition of Both," 86 YALE L.J. 1273, 1283 (1977). 
the task of restoring the vitality of the doctrine of enumerated powers. As with his federalism principle, the historical basis of the doctrine is important to Justice Rehnquist. ${ }^{188} \mathrm{He}$ is, of course, unhappily aware of the doctrine's gradual disappearance from the Court's jurisprudence:

[O]ne of the greatest "fictions" of our federal system is that Congress exercises only those powers delegated to it, while the remainder are reserved to the States or to the people. . . Although it is clear that the people, through the States, delegated authority to Congress to "regulate Commerce . . . among the several states," . . . one could easily get the sense from this Court's opinions that the federal system exists only at the sufferance of Congress. ${ }^{189}$

Justice Rehnquist has proposed a number of devices that would confine Congress to the exercise of only "those powers delegated to it." He has endorsed the rehabilitation of the pre-New Deal nondelegation doctrine, arguing in a recent case that a provision of the 1970 Occupational Safety \& Health Act was an impermissible delegation of legislative authority to an executive officer. ${ }^{190} \mathrm{He}$ has marshalled a majority of the Justices to support a holding that "if Congress intends to impose a condition on the grant of federal moneys, it must do so unambiguously." "191 And he has insisted on applying a higher level of scrutiny to federal legislation than to state action. Federal and state laws are both subject to judicial review to determine whether some constitutional limitation on the relevant government has been violated. Since federal, but not state, power is specifically enumerated, Rehnquist argues that courts must entertain attacks on federal, but not state, laws based on the claim that Congress has exceeded its grant of authority. ${ }^{192}$ But Rehnquist's major efforts to reinvigorate the idea of limited federal government have been in the areas of the commerce clause and the Fourteenth Amendment.

188. "The First Amendment was adopted . . . at a time when the Federal Government was in a real sense considered a government of limited delegated powers. Indeed, the principal argument against adopting the Constitution without a "Bill of Rights" was not that such an enactment would be undesirable, but that it was unnecessary because of the limited nature of the Federal Government." Thomas v. Review Bd. of the Ind. Employment Sec. Div., 450 U.S. 707, 721 (1981) (Rehnquist, J., dissenting) (emphasis in original).

189. Hodel v. Virginia Surface Mining \& Reclamation Ass'n, 452 U.S. 264, 307-08 (1981) (Rehnquist, J., concurring). Justice Rehnquist's opinion concurs in the judgments in both Virginia Mining, and Hodel v. Indiana, 452 U.S. 314 (1981).

190. Industrial Union Dep't, AFL-CIO v. American Petroleum Inst., 448 U.S. 607, 671-88 (1980) (Rehnquist, J., concurring).

191. Pennhurst State School \& Hosp. v. Halderman, 451 U.S. 1, 17 (1981).

192. See Hodel v. Virginia Surface Mining \& Reclamation Ass'n, 452 U.S. 312-13 (1981) (Rehnquist, J., concurring). 


\section{A. The Commerce Clause}

The commerce clause has been prominently linked with Justice Rehnquist's federalism since the two collided in Usery. That decision, however, purported to discern no new internal limits to the congressional commerce power, which it stated is "plenary."193 Usery's holding that Congress would not extend federal minimum wage/maximum hour requirements to state employees was "not because Congress . . . lack[s] an affirmative grant of legislative authority to reach the matter, but because the Constitution prohibits it from exercising the authority in that manner." 194 In terms of Rehnquist's theory of judicial review, the federal action in Usery was invalidated because it transgressed a constitutional limit on federal legislation, and not because it exceeded the Constitution's affirmative grant of authority over interstate commerce to Congress.

But even in Usery the distinction between challenging "the breadth of authority granted Congress under the commerce power" and asserting "an affirmative limitation on the exercise" of that power proved difficult to maintain. ${ }^{195}$ At times the Usery opinion seems to admit that its state sovereignty doctrine can be read as a limit on the commerce power internal to the commerce clause. ${ }^{196}$ This is more than just a semantic point; later cases increasingly call into question the seriousness of Justice Rehnquist's commitment to the post-1937 orthodoxy that the commerce power is plenary.

Justice Rehnquist insists that his higher level scrutiny of federal legislation requires the Court to examine critically the connection with interstate commerce that Congress asserts as the basis for its legislative competence.

In short, unlike the reserved police powers of the States, which are plenary unless challenged as violating some specific provision of the Constitution, the connection with interstate commerce is itself a jurisdictional prerequisite for any substantive legislation by Congress under the Commerce Clause. ${ }^{197}$

193. 426 U.S. at 840 .

194. Id. at 845 .

195. Id. at 841 .

196. "We hold that insofar as the challenged amendments operate to directly displace the States' freedom to structure integral operations in areas of traditional governmental functions, they are not within the authority granted Congress by Art. I, $\S 8, \mathrm{cl} .3$. ." Id. at 852 . "Interference with integral governmental services provided by . . . subordinate arms of a state government is therefore beyond the reach of congressional power under the Commerce Clause." Id. at 855-56 n.20. The nationalist tradition of viewing the commerce power as plenary, which dates back to the Marshall Court, seems to have forced Justice Rehnquist to avoid recognizing explicitly that his state sovereignty doctrine functions in the same way that an "internal" limit to the commerce clause would. Although he struggles mightily to endorse both plenary congressional power and state autonomy, his effort fails even rhetorically, as the quotations in this footnote illustrate.

197. Hodel v. Virginia Surface Mining \& Reclamation Ass'n, 452 U.S. 265, 311 (1981) (Rehn- 
Rehnquist's negative attitude toward the exercise of the commerce power combined with his solicitude for the plenary legislative authority reserved to the states makes him extremely reluctant to find that state law is invalid either because it conflicts with federal legislation or with the commerce clause's latent scope.

In Jones v. Rath Packing Co. ${ }^{198}$ and Ray v. Atlantic Richfield Co., ${ }^{199}$ Justice Rehnquist made it clear that under his view of the commerce clause, congressional preemption of a field of commerce law is not to be inferred lightly. In Rath Packing, the Court decided inter alia that the federal Fair Packing \& Labeling Act implicitly preempted a California statute restricting the weight variations allowed in packaged flour. Rejecting this holding, Justice Rehnquist wrote: "This latter pre-emption is founded in unwarranted speculations that hardly rise to that clear demonstration of conflict that must exist before the mere existence of a federal law may be said to pre-empt state law operating in the same field." ${ }^{200}$ Ray involved the constitutionality of Washington State's Tanker Law. A federal district court held the law void in its entirety due to preemption by the federal Ports \& Waterways Safety Act. The Supreme Court upheld parts of the Washington law, but affirmed the lower court's judgment as to the rest. Justice Rehnquist joined Justice Marshall's opinion dissenting as to the invalidation of the provision of the Tanker Law prohibiting the operation in Puget Sound of tankers exceeding 125,000 deadweight tons. The separate opinion argued both that the federal Act did not of its own force conflict with the state size limitation, and that it had not been demonstrated that the Department of Transportation had addressed the issue in its regulations promulgated under the Act. Since the size limit had not been shown to be an irrational means of protecting human and environmental safety, or substantially burdensome on foreign commerce, federal preemption should not be inferred. ${ }^{201}$

The Court's role in reviewing state legislation under the commerce clause where there is no federal statute at all should be even more limited, according to Justice Rehnquist. In Hughes v. Oklahoma, ${ }^{202}$ the appellant was arrested by a state game warden for violating an Oklahoma statute prohibiting the transportation out-of-state of minnows taken from their natural habitat in commercially significant numbers. Hughes was convicted and the conviction was affirmed by the state Court of Criminal Appeals. The United States Supreme Court reversed, stating that the law

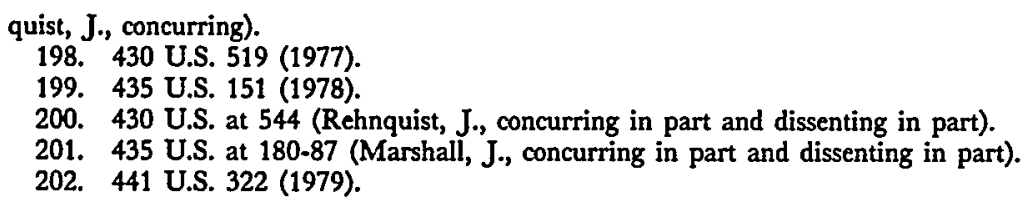


on its face discriminated against interstate commerce, and was not the least discriminatory means available to achieve the state's goal of conserving its wildlife. The Court's opinion recalled that the commerce clause reflects one of the principle goals of the Constitutional Convention: "[T]he conviction that in order to succeed, the new Union would have to avoid the tendencies toward economic Balkanization that had plagued relations among the Colonies and later among the States under the Articles of Confederation." ${ }^{203}$ The importance of this constitutional goal and the facially discriminatory nature of the state statute warranted "the strictest scrutiny."204

Justice Rehnquist was unconvinced. In particular, he disagreed with the majority's standard of review. In his view, a state law implementing the state's special interest in preserving its wildlife should be reviewed only to determine whether the law "directly conflicts with a federal statute or treaty, ... allocates access in a manner that violates the Fourteenth Amendment, ... or represents a naked attempt to discriminate against out-of-state enterprises in favor of in-state businesses unrelated to any purpose of conservation." ${ }^{205}$ Applying this standard of review, Justice Rehnquist found no infirmity in the Oklahoma statute. The possibility that such undemanding scrutiny of state laws will undercut the "economic unitarianism" the majority wished to foster simply did not matter to Rehnquist.

The different standards of review adopted by the Hughes majority and by Justice Rehnquist resulted in another Rehnquist dissent in Kassel $v$. Consolidated Freightways Corp. ${ }^{206}$ In Kassel, a six-Justice majority struck down an Iowa law barring the use on its highways of trucks longer than sixty feet. Four Justices concluded that lowa had not demonstrated a sufficient connection between the law and highway safety to justify the infringement on free interstate commerce. Two Justices concurred in the judgment but would have held that the legislative history of the law showed its purpose to be reducing the amount of interstate traffic through Iowa, an objective always impermissible under the commerce clause. Justice Rehnquist wrote for the three dissenters. He maintained that the decision once again had overstepped the Court's limited authority to review state laws under the "negative side" of the commerce clause, and that it "seriously intrudes upon the fundamental right of the States to pass laws to secure the safety of their citizens." 207

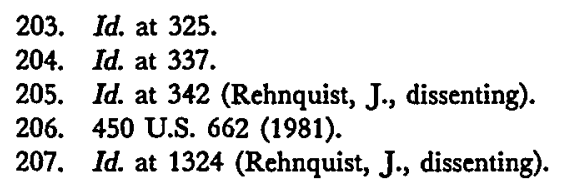


The relationship between Rehnquist's theory of a limited commerce clause and his theory of federalism emerged clearly in Reeves, Inc. $v$. Stake, ${ }^{208}$ a case in which Justice Rehnquist joined the majority opinion written by Justice Blackmun. Reeves arose from the 1978 decision of the South Dakota Cement Commission to restrict the sale of cement from its half-century old cement plant to South Dakota residents. The petitioner, an out-of-state purchaser, was forced as a result to cut its activities severely. A federal district court declared the restriction unconstitutional, but was reversed by the court of appeals. The Supreme Court affirmed, applying the state-as-market-participant/state-as-market-regulator distinction first mentioned in Hughes v. Alexandria Scrap Corp. ${ }^{209}$ The Court stated that the commerce clause is directed only to the state as regulator. The majority also rested its decision on the state sovereignty doctrine: "States may fairly claim some measure of a sovereign interest in retaining freedom to decide how, with whom, and for whose benefit to deal.".210

\section{B. The Fourteenth Amendment}

Perhaps Justice Rehnquist's greatest challenge in his fight to revitalize federalism has been his effort to limit the Fourteenth Amendment in order to minimize the states' vulnerability to federal power. The Amendment on its face purports to limit the powers of the states and to expand the power of the federal government. Whatever structure of federalism the Constitution of 1787 created was undeniably modified to some extent by the Amendment, a fact that Rehnquist of course concedes. But while he admits that the Fourteenth Amendment and its companions, the Thirteenth and Fifteenth, were intended to "sharply [alter] the balance of power between the Federal and State Governments," Justice Rehnquist insists that the amendments

were not designed to accomplish this purpose in some vague, ill-defined way which was ultimately to be discovered by this Court more than a century after their enactment. Their language contained the mechanisms by which their purpose was to be accomplished. Congress might affirmatively legislate under $\S 5$ of the Fourteenth Amendment to carry out the purposes of that Amendment; and the courts could strike down state laws found directly to violate the dictates of any of the [Civil War] Amendments.

This was strong medicine, and intended to be such. But it cannot be

210. 447 U.S. at 438 n.10. 
read apart from the original understanding at Philadelphia $\ldots .^{211}$

In order to preserve that "original understanding," Rehnquist has employed a number of judicial devices that minimize the impact of the Civil War Amendments.

\section{Section Five}

One such device is a limiting construction of the enforcement power granted Congress under section five of the Fourteenth Amendment, and under the equivalent provisions of the Thirteenth and Fifteenth Amendments. These sections, according to Justice Rehnquist, grant Congress "only the power to 'enforce' by 'appropriate' legislation the limitations on state action embodied in those Amendments." 212 Thus, in City of Rome v. United States, ${ }^{213}$ Justice Rehnquist dissented from a decision holding that the petitioner, a political subdivision of a state wholly covered by the preclearance provisions of the 1965 Voting Rights Act, could not "bailout" of coverage on its own. ${ }^{214}$ Rehnquist vigorously attacked the Court's decision as an abdication to Congress of the power to construe the meaning of "enforce" and "appropriate" in the Fourteenth and Fifteenth Amendments. While conceding that the Amendments grant Congress power to prohibit some conduct not in itself violative of the Amendments, Rehnquist argued that this power is exercised "appropriately" to "enforce" the Amendments only "if that prohibition is necessary to remedy prior constitutional violations by the governmental unit, or if necessary to effectively prevent purposeful discrimination ....".215 Congress must identify the wrong of constitutional dimensions that it is remedying so that "the appropriateness of the remedy [can] be measured."216 Legislation that is not addressed to a constitutional wrong, that is not an appropriate remedy, or that penalizes a party not itself guilty of constitutional wrongdoing (the situation in Gity of Rome, according to Justice Rehnquist), is beyond the competence of Congress.

Rehnquist used a second method of limiting the impact of the Fourteenth Amendment in writing for the Court in Pennhurst State School \&

211. Trimble v. Gordon, 430 U.S. 762,778 (1977) (Rehnquist, J., dissenting).

212. Gity of Rome v. United States, 446 U.S. 156, 207 (1980) (Rehnquist, J., dissenting) (emphasis added).

213. Id.

214. The Act imposes certain restrictions on covered states and their political subdivisions from these restrictions, 42 U.S.C. § 1973b (1976). The Voting Rights Act Amendents of 1982 permit subdivisions of covered states to bail-out of coverage on their own. Pub. L. No. 97-205, § 2, 96 Stat. 131.

215. 446 U.S. at 213 .

216. Id. 
Hospital v. Halderman. ${ }^{217}$ The respondents in Halderman claimed that by accepting federal funds the state institution involved had obliged itself to implement congressional guidelines specified in the 1975 Bill of Rights of Institutionalized Persons. ${ }^{218}$ Rehnquist conceded that Congress might be able to impose such a condition on the states when exercising its powers under section five of the Fourteenth Amendment, but insisted that the Court would not infer that Congress had intended to use those powers absent an explicit congressional declaration to that effect. ${ }^{219}$ This surprising departure from the usual presumption that Congress intends to exercise all its powers when legislating makes perfect sense in terms of Justice Rehnquist's solicitude for state autonomy.

\section{Equal Protection}

Justice Rehnquist's most fundamental method of minimizing the Fourteenth Amendment lies in his familiar resort to the "intention of the Framers," who for this purpose are presumably the federal legislators who drafted the Amendment and sent it to the states for ratification. Rehnquist has steadfastly opposed the Court's use of the Amendment's equal protection clause in areas other than race on the ground that such use is beyond "the intent of the framers of the Fourteenth Amendment." ${ }^{220}$ For example, in Sugarman v. Dougall, Rehnquist dissented from the Court's decision invalidating on equal protection grounds a New York law restricting state civil service positions to United States citizens. ${ }^{221}$ The precedential basis for Sugarman was the Court's decision in Graham v. Richardson that alienage was to be considered a suspect classification for equal protection purposes because aliens constitute a "discrete and insular minority" unable to defend themselves adequately through the political process. ${ }^{222}$ Rehnquist's opinion attacked both the Sugarman decision and its Graham underpinnings:

The principal purpose of those who drafted and adopted the Amendment was to prohibit the States from invidiously discriminating by reason of race . . . . But there is no language used in the Amendment, or any historical evidence as to the intent of the Framers, which would suggest to the slightest degree that it was intended to render alienage a "suspect" classification, that it was designed in any way to protect "discrete and insular minorities" other than racial

217. 451 U.S. 1 (1981).

218. 42 U.S.C. $\$ 6000$ (Supp. IV 1980).

219. 451 U.S. at 15-18.

220. Cruz v. Beto, 405 U.S. 319, 326 (1972) (Rehnquist, J., dissenting).

221. 413 U.S. 634,649 (1973).

222. 403 U.S. 365,372 (1971). 
minorities, or that it would in any way justify the result reached by the Court in [Sugarman]. ${ }^{223}$

Justice Rehnquist is equally hostile, on the same historical grounds, to equal protection strict scrutiny when it is extended beyond race to protect "fundamental rights." In Weber v. Aetna Casualty \& Surety Co., ${ }^{224}$ the Supreme Court overturned on equal protection grounds a Louisiana statute that denied unacknowledged illegitimate children recovery rights under a workmen's compensation statute upon their father's death. In lone dissent, Rehnquist criticized the Court's use of strict scrutiny:

The difficulty with this approach, devoid as it is of any historical or textual support in the language of the Equal Protection Clause, is that it leaves apparently to the Justices of this Court the determination of what are, and what are not, "fundamental personal rights." ... While the Court's opinion today is by no means a sharp departure from the precedents on which it relies, it is an extraordinary departure from what I conceive to be the intent of the framers of the Fourteenth Amendment. ${ }^{225}$

\section{Due Process}

In similar fashion, Justice Rehnquist advocates the acceptance of limits derived from history on the Fourteenth Amendment's due process clause. Opposing the Court's recognition in Roe v. Wade ${ }^{226}$ of a constitutional right to privacy in conflict with many state abortion laws, Rehnquist wrote: "To reach its result, the Gourt necessarily has had to find within the scope of the Fourteenth Amendment a right that was apparently completely unknown to the drafters of the Amendment." ${ }^{327}$ Enforcing such a right cannot, in Justice Rehnquist's view, be reconciled with fidelity to the drafters' "intent."

Adherence to the intention of the Fourteenth Amendment's framers also provides the basis for Justice Rehnquist's systematic rejection of the doctrine of the selective incorporation of Bill of Rights guarantees into the Amendment's due process clause. ${ }^{228}$ Justice Rehnquist's disdain for the

223. 413 U.S. at $649-50$ (1973) (Rehnquist, J., dissenting).

224. 406 U.S. 164 (1972).

225. Id. at 179-81 (Rehnquist, J., dissenting).

226. 410 U.S. 113 (1973).

227. Id. at 174 (Rehnquist, J., dissenting).

228. Justice Black insisted that the Fourteenth Amendment's framers intended deprivation of liberty "without due process of law" to mean "without complying with the Bill of Rights." Black, The Unfinished Business of the Warren Court, 46 WASH. L. REV. 3, 34 (1970). His historical claims were hotly disputed, see Fairman, Does the Fourteenth Amendment Incorporate the Bill of Rights? The Original Understanding, 2 STAN. L. REV. 5 (1949), and his view never commanded the support of a 
incorporation doctrine as an interpretation of the Fourteenth Amendment is open. He customarily refers to "incorporation" and "incorporated" in quotation marks, ${ }^{229}$ and has referred to "the mysterious process of transmogrification by which [a guarantee of the Bill of Rights] was held to be 'incorporated' and made applicable to the States by the Fourteenth Amendment.." ${ }^{230} \mathrm{He}$ has characterized incorporation as "another judicial building block" used by the Court to construct constitutional doctrine with an "increasingly remote" and even "incomprehensible" connection to the Constitution's text. ${ }^{231}$ Although he accepts the Court's use of the Bill of Rights as a series of "points of reference" helpful in determining how to apply the "flexible analytical 'tools' provided by the Equal Protection Clause and the Due Process Clause," ${ }^{232}$ he denies that the first eight amendments are determinative of the meaning of the Fourteenth.

Justice Rehnquist's Fourteenth Amendment jurisprudence has been most fully articulated in relation to the "incorporation" of the First Amendment into the Fourteenth. In his separate opinion in Buckley v. Valeo, ${ }^{233}$ Justice Rehnquist wrote:

I am of the opinion that not all of the strictures which the First Amendment imposes upon Congress are carried over against the States by the Fourteenth Amendment, but rather that it is only the 'general principle' of free speech, that the latter incorporates.

Given this view, cases which deal with state restrictions on First Amendment freedoms are not fungible with those which deal with restrictions imposed by the Federal Government . . . . ${ }^{234}$

majority on the Court, which instead has over the years selectively incorporated provisions of the Bill of Rights regarded as fundamental "to an Anglo-American regime of ordered liberty." Duncan v. Louisiana, 391 U.S. 145, 149 n.14 (1968).

229. E.g., Carter v. Kentucky, 450 U.S. 288, 309 (1981) (Rehnquist, J., dissenting); Hutto v. Finney, 437 U.S. 678, 717 (1978) (Rehnquist, J., dissenting); Paul v. Davis, 424 U.S. 693, 710 n.5 (1976).

230. Carter v. Kentucky, 450 U.S. 288, 309 (1981).

231. Snead v. Stringer, 102 S. Ct. 535, 536 n.1 (1981) (Rehnquist, J., dissenting from denial of cert.).

232. Nevada v. Hall, 440 U.S. 410,441 n.6 (1979) (Rehnquist, J., dissenting).

233. 424 U.S. 1 (1976).

234. Id. at 291 (Rehnquist, J., concurring in part and dissenting in part) (citations omitted). Rehnquist's opinion credited Justice Jackson's dissent in Beauharnais v. Illinois and Justice Harlan's dissent in Roth $v$. United States with devising the basis for his position. Justice Jackson's Beauharnais opinion stated in part that

[a]s a limitation upon power to punish written or spoken words, Fourteenth Amendment "liberty" in its context of state powers and functions has meant and should mean something quite different from "freedom" in its context of federal powers and functions . . . . Any superficial inconsistency between applying the same standard [clear and present dangers test] but permitting a wider range of action to the States is resolved upon reference to the latter part of the statement of the formula: clear and present danger of those substantive evils which the legislature has a right to prevent. The evils at which Congress may aim, and in doing so come into conflict with free speech, will be relatively little since it is a government of limited powers. Because the States may reach more evils, they will have wider range to punish speech which 
One of Justice Rehnquist's most significant opinions in this area is his dissent in First National Bank of Boston v. Bellotti. ${ }^{235}$ The case involved a Massachusetts statute prohibiting business corporations organized or operating in the state from spending corporate funds for the purpose of influencing the vote in any state referendum not specifically and materially affecting their assets or business. With an eye toward an upcoming referendum on a constitutional amendment to impose an individual income tax opposed by the managements of many large businesses and banks, the state legislature included in the law a provision specifying that no referendum issue concerning taxes on individuals would be deemed to fall within the "materially affecting" exception to the general ban on expenditures. The state argued that it had a legitimate interest in preventing corporate money from dominating the public discussion of the proposed amendment and in protecting the rights of stockholders who disagreed with their management's stand on the issue.

The Massachusetts Supreme Judicial Court upheld the statute, ${ }^{236}$ but the United States Supreme Court reversed. The five-Justice majority reasoned that speech protected by the First and Fourteenth Amendments does not lose its protected character simply because it is spoken by a corporation. Justice Powell's opinion for the Court noted the absence of specific legislative findings that the democratic process was endangered by corporate expenditures. It also held that, as a protection for dissenting stockholders, the statute was both underinclusive (corporate activity with respect to proposed legislation was still permitted) and overinclusive (a corporation was prohibited from spending money for a cause sanctioned by a vote of all its stockholders). ${ }^{237}$ Justices White, Brennan, and Marshall dissented substantially for the reasons given by the state in defense of the statute.

Justice Rehnquist's separate dissent took a different tack. While expressing the view that the Massachusetts court's decision was probably compatible with the view of the First Amendment held by the other Jus-

presents clear and present danger of bringing about those evils.

343 U.S. 250, 288, 299 (1952). Justice Harlan wrote in his Roth opinion that:

our function in reviewing state judgments under the Fourteenth Amendment is a narrow one.

... We can inquire only whether the state action so subverts the fundamental liberties implicit in the Due Process Clause that it cannot be sustained as a rational exercise of power . . . The States' power to make printed words criminal is, of course, confined by the Fourteenth Amendment, but only insofar as such power is inconsistent with our concepts of 'ordered liberty.'. . . I do not think it follows that state and federal powers in this area are the same, and that just because the State may suppress a particular utterance, it is automatically permissible for the Federal Government to do the same.

354 U.S. 476, 501, 503 (1957).

235. 435 U.S. 765 (1978).

236. 371 Mass. 773,359 N.E.2d 1262 (1976).

237. 435 U.S. at 793-94. 
tices, Rehnquist also stated:

I am certain that under my views of the limited application of the First Amendment to the States, which I share with the two immediately preceding occupants of my seat on the Court [Justices Jackson and Harlan], but not with my present colleagues, the judgment of the Supreme Judicial Court of Massachusetts should be affirmed. ${ }^{238}$

As indicated by his earlier opinions this meant that Justice Rehnquist would examine the Massachusetts statute only for its "rational relation to a valid state objective"239 and for its congruence with "the 'general principle' of free speech." ${ }^{240}$

The dissent proceeds according to these announced principles. The economic purposes for which the state creates a business corporation or admits it into its jurisdiction are limited. They do not require vesting the corporation with "all the [liberties] enjoyed by natural persons," but only with those necessary to the protection of the corporation's business or property. ${ }^{241}$ It is perfectly rational, Rehnquist continues, for the state legislature to conclude that the economic benefits conferred on corporations "pose special dangers in the political sphere" and that the rights of political expression in general "are not at all necessary to effectuate the purposes for which States permit corporations to exist."242 Thus, the statute, which was construed by the Massachusetts high court to permit corporate political expression when a referendum genuinely affects corporate business or property, possessed the necessary "rational relation" to the valid state objectives of regulating the commercial organizations on which it had conferred special benefits and of protecting the political process.

Furthermore, argues Rehnquist, the statute is in accord with the "general principle" of free speech. In his view,

[t]he free flow of information is in no way diminished by the Commonwealth's decision to permit the operation of business corporations with limited rights of political expression. All natural persons, who owe their existence to a higher sovereign than the Commonwealth, remain as free as before to engage in political activity. ${ }^{243}$

Therefore, "[t]he statute as construed provides at least as much protection

238. Id. at 823 (Rehnquist, J., dissenting).

239. Roe v. Wade, 410 U.S. 113, 173 (1972) (Rehnquist, J., dissenting).

240. Buckley v. Valeo, 424 U.S. 1, 291 (1975) (Rehnquist, J., dissenting).

241. 435 U.S. at 825 n.4 (Rehnquist, J., dissenting).

242. Id. at 826 .

243. Id. at 828 . 
as the Fourteenth Amendment requires."244

Rejection of selective incorporation as a substantive interpretation of the Fourteenth Amendment has a limiting effect on the section five enforcement powers of Congress. Because liberties guaranteed by the Bill of Rights are only indirectly related to the Fourteenth Amendment, Congress's power to protect them by legislation is more limited than its power to enforce guarantees, such as the equal protection clause (limited presumably to race), which are contained in haec verba in the Amendment. ${ }^{245}$

At least verbally, Justice Rehnquist's interpretation of Fourteenth Amendment "liberty" is the same as that of the second Justice Harlan. Rehnquist has written that "the 'liberty' against deprivation of which without due process the Fourteenth Amendment protects, embraces more than the rights found in the Bill of Rights, ${ }^{246}$ a statement that echoes Harlan's views. ${ }^{247}$ For Justice Rehnquist, state law, not federal law, is determinative of the content of "the finite class of liberty interests protected" by the Amendment. ${ }^{248}$ Rehnquist's view leaves open the possibility that a state can reduce the sphere of liberties it may not infringe under the due process clause simply by refusing (or failing, as in Paul v. Davis) to define particular interests as rights. Justice Harlan, on the other hand, believed that the federal courts could recognize individual rights "implicit in the concept of ordered liberty" although not "assured by the letter or penumbra of the Bill of Rights," ${ }^{249}$ and could protect them against interference regardless of whether a state recognized them as rights.

The two Justices' approaches to the Fourteenth Amendment also differ as to the proper standard of review in due process cases. Harlan thought that the Amendment guarantees individuals "freedom from all substantial arbitrary impositions and purposeless restraints" by state governments. ${ }^{250}$ Harlan, therefore, accepted the need for a "particularly careful scrutiny of the state needs asserted to justify [such restraints]." ${ }^{251}$ Justice Rehnquist's contrasting view embodies his federalism principle: state legislation affect-

244. Id. Justice Rehnquist's view of the relationship of the Bill of Rights to the Fourteenth Amendment is not limited to the First Amendment area. See for example his concurrence in Justice Powell's dissent in Crist v. Bretz, 437 U.S. 28, 40 (1978). The Crist majority held that the Fifth Amendment rule attaching jeopardy in a jury trial when the jury is empanelled and sworn in applies to the states under the Fourteenth Amendment. The dissenters argued that even if the rule is part of the Fifth Amendment it should not be imposed on the states since it is not "fundamental to the guarantees of the Double Jeopardy Clause." Id. at 52 (Powell, J., dissenting).

245. Hutto v. Finney, 437 U.S. 678, 717 (1978) (Rehnquist, J., dissenting) (suggesting that Congress had less authority to enforce Eighth Amendment prohibition of cruel and unusual punishment against the states than to enforce equal protection clause).

246. Roe v. Wade, 410 U.S. 113, 172-73 (1973) (Rehnquist, J., dissenting).

247. See Poe v. Ullman, 367 U.S. 497, 543 (1961) (Harlan, J., dissenting).

248. Santosky v. Kramer, 102 S. Ct. 1388, 1405 (1982) (Rehnquist, J., dissenting).

249. Griswold v. Connecticut, 381 U.S. 479, $499-500$ (1965) (Harlan, J., concurring).

250. Poe v. Ullman, 367 U.S. 497, 543 (1961) (Harlan, J., dissenting).

251. Id. 
ing Fourteenth Amendment liberties (themselves defined by the state) can be reviewed by a federal court only for its "rational relation to a valid state objective,",252 and possibly for its congruence with certain values so central to a republican polity that no state could constitutionally render them unprotected by failing to recognize them as protected interests. ${ }^{253}$

\section{Evaluating Justice Rehnquist's Federalism}

Justice Rehnquist was appointed by a president who sought to identify himself with "strict constructionism," and many of the Justice's present admirers are devout believers in judicial restraint and in a close adherence to the letter of the Constitution. Rehnquist himself has severely criticized innovative constructions of the Constitution ${ }^{254}$ and has indicted the Court for its use of its own precedents and of the selective incorporation doctrine as "Constitutional building blocks . . . piled on top of one another so that the connection between the original provision in the Constitution and the application in a particular case is all but incomprehensible."25s One might assume, therefore, that Rehnquist's own judicial work would be marked by deference to the other branches of government, and by a literalistic exegesis of the Constitution's text.

Rhetoric notwithstanding, however, Justice Rehnquist is clearly and consciously, not a strict constructionist and not a practitioner of judicial restraint. He has consistently based his central doctrine of federalism on "fundamental principles" that are "reflected" in the Tenth Amendment, "embodied" in the Eleventh Amendment, ${ }^{257}$ and "illustrated" by Younger v. Harris. ${ }^{258}$ This method of constitutional analysis has the great advantage of avoiding the limitations that might result from too close attention to the language or history of specific constitutional provisions or to the factual setting of a judicial precedent. It provides his federalism principle with an almost unlimited capacity for expansion, as the remarkable growth of the Younger doctrine illustrates. But this willingness to discover constitutional truth in the interstices of that document is poles apart from strict constructionism. Moreover, to implement "his federalism" Justice

252. Roe v. Wade, 410 U.S.113, 173 (1973) (Rehnquist, J., dissenting).

253. One such value is the " 'general principle' of free speech." Buckley v. Valeo, 424 U.S. 1, 291 (1976) (Rehnquist, J., concurring in part and dissenting in part) (quoting Gitlow v. New York, 268 U.S. 652, 672 (1925) (Holmes, J., dissenting)). See also Brown v. Hartlage, 102 S. Ct. 1523, 1533 (1982) (Rehnquist, J., concurring in result) (provision of state corrupt practices act "impermissibly limits freedom of speech in violation of the First and Fourteenth Amendments").

254. Rehnquist, supra note 13.

255. Snead v. Stringer, 102 S. Ct. 535, 536 \& n.1. (1981) (Rehnquist, J., dissenting from denial of cert.).

256. Fry v. United States, 421 U.S. 542, 556 (1975) (Rehnquist, J., dissenting).

257. Fitzpatrick v. Bitzer, 427 U.S. 445,456 (1976).

258. Fair Assessment in Real Estate Ass'n v. McNary, 102 S. Ct. 177, 184 (1981). 
Rehnquist has been obliged to adopt an extremely aggressive and activist role. Usery, after all, was an extraordinary instance of judicial activism, involving as it did the invalidation of an exercise of Congress's "plenary" commerce power on the basis of a doctrine nowhere to be found in the words of the Constitution.

These characteristics of Justice Rehnquist's judicial work-his activism, his refusal to be bound by text or precedent, ${ }^{259}$ and his invocation of "principles" only loosely connected to specific constitutional provisions-appear at first glance to be precisely the sort of constitutional emotivism that he denounced in his Article on "The Notion of a Living Constitution."200 Is he, then, simply inconsistent, caught in the same "web of subjectivity"261 that he claims controls and mars contemporary constitutional discourse? The answer Justice Rehnquist would surely give is that his judicial record reflects not the imposition of his own values but rather his fidelity to the intention of the Constitution's Framers. The central motifs of his constitutional decisions, the sovereign state and the limited federal government, were also, Rehnquist claims, the guiding principles of "those who drafted and ratified the Constitution."262 They are admittedly quite unlike the details of the constitutional scheme, such as the provisions that each state should have two senators ${ }^{263}$ and that the executive power should be vested in one president. ${ }^{264}$ Such specific, technical provisions were necessarily committed to the text. The twin principles of federalism, on the other hand, pervade the Constitution in its entirety. They are its "tacit postulates," argues Rehnquist, the goals that the text's details were intended to implement. As a constitutional theorist of an earlier era put it: "[G]an any historical fact be more demonstrable than that the States did, both in the Confederation and in the Union, retain their sovereignty and independence as distinct communities? . . . The Constitution . . . in fact . . . is full of statehood." ${ }^{265}$ Since for Rehnquist this version of the Framers' intent is historically demonstrable, it can serve as a refuge from the subjectivity of emotivism.

But if Justice Rehnquist's claim to have discovered the key to objective constitutional analysis is to succeed, it must withstand scrutiny of both its analytical coherence and its historical accuracy. Three questions must be

259. See, e.g., Nevada v. Hall, 440 U.S. 410, 433-34 (1979) (Rehnquist, J., dissenting) (criticizing majority for "literalism" in its construction of Constitution); Weber v. Aetna Casualty \& Surety Co., 406 U.S. 164, 177 (1972) (Rehnquist, J., dissenting) (precedent not as binding in constitutional law as in other areas).

260. 54 TEX. L. REV. 693 (1976).

261. See A. BICKEL, THE SUPREME COURT AND THE IDEA OF PROGRESS 47 (1970).

262. Fry v. United States, 421 U.S. 542, 557 (1974) (Rehnquist, J., dissenting).

263. U.S. CONST. art. I, $\S 3$, cl. 1.

264. Id. art. II, $\S 1$, cl. 1 .

265. J. DAVIS, supra note 185 , at $2,130$. 
asked. First, is Rehnquist's theory of federalism internally consistent? Second, does the Justice apply it consistently as a principled basis for decision rather than as window-dressing? Finally, does it genuinely rest on a demonstrable historical basis that can serve as an objective constitutional norm?

\section{A. The Theory's Internal Consistency}

The answer to the first question is yes: Justice Rehnquist's federalism does form a consistent constitutional theory. The core of the theory is the idea of state sovereignty, understood in traditional fashion as autonomous state power. ${ }^{266}$ The Usery decision explicitly states this idea, noting that there are areas of legislative competence within which the states have final authority. Rehnquist's insistence that the states' political subdivisions be given a similar degree of autonomy is rooted in the fact that it is through these subdivisions that the states actually exercise many of their powers. Furthermore, if the states are truly to be autonomous sovereigns within the sphere of their reserved powers, the principle of federalism must shield their activities not only from federal legislation, but also from federal judicial ${ }^{267}$ and executive interference. ${ }^{268}$

State executive agencies and courts, however, are only instrumentalities, not ends in themselves. They implement the goals and public policies chosen by the states' lawmaking authorities. Talk of state sovereignty would be somewhat chimerical if these instrumentalities were immune from federal tampering but the central government could still choose for the states what goals they could pursue. To give substance to state autonomy, state substantive law must also be shielded from federal intrusion as much as possible. This entails not only construing federal laws in ways that avoid supplanting state laws on related subjects, but also a peculiar view of the federal Constitution itself. The Constitution mentions concepts such as "liberty" and "property," which it protects against state deprivation without "due process." If substantive federal definitions of these concepts may be derived from the Constitution itself, then the states will not in fact possess legislative autonomy: the United States Constitution (as interpreted by the Court), and not a state legislature or supreme court will be the ultimate arbiter in disputes over what "liberty" interests in reputation

266. For this understanding of sovereignty, see, for example, ARISTOTLE, POLITICS 1278 b; T. HOBbES, LEVLATHAN (pt. II) chs. $27-28$ (1651); J.S. MILL, REPRESENTIVE GOVERNMENT ch. 5 (1861).

267. Rizzo v. Goode, 423 U.S. 362 (1976).

268. United Gredit Bureau v. NLRB, 102 S. Ct. 539 (1981) (Rehnquist, J., dissenting from denial of cert.). 
a state will protect. ${ }^{269}$ Therefore, a thoroughgoing state sovereignty doctrine requires that the Constitution limit the states, for the most part, only in formal and certain procedural ways.

The principle of a federal government limited to enumerated and restricted powers is also essential to state sovereignty. The latter will wither on the vine if the federal government's sphere of competence is effectively unbounded, as by an expansive construction of the necessary and proper clause, or if the federal government's enumerated powers are themselves capable of congressional expansion unrestricted by judicially enforceable limits, as was true of the pre-Usery commerce clause. Energized by the supremacy clause, federal rules created by Congress and Court inevitably tend to supplant state law. The constitutionalizing of the law of defamation by the Supreme Court, ${ }^{270}$ and the displacement of much corporation law by the federal securities statutes, ${ }^{271}$ are only two examples of how this process can take place within legal areas that are clearly a part of the state sphere. If sovereignty is to mean real autonomy, the states must be free from federal encroachment in their internal workings as well as in their external activities. This can only be accomplished by setting effective boundaries on the powers delegated to the central government. For example, in Pennhurst State School \& Hospital v. Halderman, the state could not reasonably claim that the federal government could under no circumstances interfere, since the state, by accepting and using federal money, had in effect entered into a "contract" with the federal government. 27 State sovereignty per se could hardly justify permitting the state to accept federal funds without agreeing to federal conditions. Justice Rehnquist's opinion for the Court, however, suggested another method of preserving some autonomy for the state in such a situation, a limit internal to the spending clause. ${ }^{273}$

\section{B. The Theory's Consistent Application}

One of the most important tests of an intellectual theory, and of a professed adherent's true devotion to it, is the theory's power to lead the adherent to decisions contrary to his or her natural inclinations. Accepting for the purposes of discussion the standard liberal view of Justice Rehnquist as a right-wing ideologue, unsympathetic to claims based on individ-

269. Paul v. Davis, 424 U.S. 693 (1976).

270. See generally W. PROSSER, THE LAW OF TORTS 819-33 (4th ed. 1971).

271. The Supreme Court appeared to halt this trend when it refused to find that the 1934 Security and Exchange Act's anti-fraud provisions impose fiduciary obligations on corporate managers. See Santa Fe Indus. v. Green, 430 U.S. 462 (1977).

272. 451 U.S. 1,17 (1981).

273. Id. at 17 n.13. 
ual liberties, and conceding that most of Rehnquist's federalism positions dovetail nicely with conservative politics, it still must be said that at times "his federalism" leads Justice Rehnquist to reach "liberal" results. PruneYard Shopping Center v. Robins ${ }^{274}$ permitted the California Supreme Court to expand the concept of a public forum for free speech purposes in that state. Moore v. Sims ${ }^{275}$ may have resulted in greater protection for Texas children who are abused by their parents. If the Court had adopted Rehnquist's position in Ray v. Atlantic Richfield Co. ${ }^{276}$ that case would have increased the environmental safety of Washington's sounds and coasts. Hughes v. Oklahoma ${ }^{277}$ invalidated an attempt by Oklahoma to conserve its wildlife, but only over Rehnquist's protests, just as Kassel v. Consolidated Freightways Corp. ${ }^{278}$ prevented lowa from protecting its motorists from the danger and annoyance posed by double-trailer trucks despite Rehnquist's arguments. If the Court had followed Justice Rehnquist's analysis in First National Bank v. Bellotti, ${ }^{279}$ Massachusetts would have been allowed to take a very reasonable step to ensure that big business and its money would not drown out other voices in a political controversy. Such decisions suggest that, at least sometimes, the Justice is willing to follow his federalism principles wherever they may lead.

\section{The Historical Basis of Rehnquist's Federalism}

The final and crucial question for Justice Rehnquist's federalism is whether it may be derived from objective historical facts. Rehnquist's constant claim, implicit or explicit, is that history "too well known to warrant more than brief mention," with the intent of the Framers and excludes alternative interpretations. But if the historical evidence is less than convincing, then Rehnquist's federalism must fail as an objective first principle.

On initial consideration, Rehnquist's historical claim seems familiar and supportable. State sovereignty and limited federal government are authentic expressions of a central strand of American constitutional philosophy that found its classic expression in the thought of Thomas Jefferson.

274. 447 U.S. 74 (1980).

275. 412 U.S. 415 (1979). Moore v. Sims involved a challenge to a Texas statute permitting the State Department of Human Resources to assume through an ex parte proceeding temporary custody of children who, it was feared, were being abused. A federal district court preliminarily enjoined the defendant state officials from utilizing the statute. The Supreme Court reversed. Justice Rehnquist's opinion for the Court stated that the district court should have abstained from interfering in ongoing state proceedings in which important state interests were involved. Id. at 423.

276. 435 U.S. 151 (1978).

277. 441 U.S. 322 (1979)

278. 450 U.S. 662 (1981).

279. 435 U.S. 765 (1978).

280. Trimble v. Gordon, 430 U.S. 762,777 (1977) (Rehnquist, J., dissenting). 
Jefferson has been called an "advocate of minimal government," and his political philosophy an effort "to splinter power in order to render it less dangerous." 281 He was completely opposed to the development of an omnicompetent national government, enforcing a unitary set of laws throughout the Union. ${ }^{282}$ In a letter to Justice William Johnson criticizing Chief Justice John Marshall's opinions for the Court in Marbury v. Madison ${ }^{283}$ and Cohens v. Virginia, ${ }^{284}$ Jefferson came very close to Justice Rehnquist's theory that federalism was the overriding intent of the Framers. Jefferson wrote that "[t]he capital and leading object of the constitution was to leave with the States all authorities which respected their own citizens only and to transfer to the United States those which respected citizens of foreign or other States, to make us several as to ourselves but one as to all others." ${ }^{285}$

In the Jeffersonian tradition, the transcendent goal of freedom is unattainable unless government-and especially national government-is kept as small and unobtrusive as possible. This vision of limited government has haunted our history from its beginning and is reflected, frequently in haec verba, in the opinions of Justice Rehnquist. Popular imagination so identifies Jefferson, the author of the Declaration of Independence, with the ideal of liberty that even the patron saint of strong national government, Abraham Lincoln, found it necessary to invoke Jefferson and his ideals, stating that " $[t]$ he principles of Jefferson are the definitions and axioms of free society." ${ }^{286}$ It is this almost canonical tradition in American cultural and intellectual history that Rehnquist's constitutional theory

281. 4 D. Malone, JefFerson AND his TiMe: JefFerson The PRESIDENT 25, 26 (1970). 282.

And I do verily believe, that if the principle were to prevail, of a common law being in force in the United States . . . it would become the most corrupt government on the earth . . . . The true theory of our Constitution is surely the wisest and best that the States are independent as to everything within themselves, and united as to everything respecting foreign nations. Let the General Government be reduced to foreign concerns only ....

Letter from Thomas Jefferson to Gideon Granger, reprinted in THOMAS JEFFERSON ON DEMOCRACY 30 (S. Padover ed. 1939).

283. 5 U.S. (1 Granch) 137 (1803).

284. 19 U.S. (6 Wheat.) 264 (1821) (Eleventh Amendment does not bar United States Supreme Court review of judgment secured by state against a defendant in its own courts).

285. See Letter, supra note 24 , at 147 . In 1821 , Jefferson wrote that "it is a fatal heresy to suppose that either our State governments are superior to the federal, or the federal to the States... . These [the people] have made coordinate, checking and balancing each other . . . each equally supreme as to the powers delegated to itself." Letter from Thomas Jefferson to anonymous correspondent (1821), reprinted in S. PADOVER, supra note 282, at 53. Jefferson abhorred the expansive interpretations of the Constitution adopted by the Marshall Court whereby "the federal branch of our government is advancing towards the usurpation of all the rights reserved to the States, and the consolidation in itself of all powers, foreign and domestic, and that, too, by construction which, if legitimate, leave no limits to their power." Letter from Thomas Jefferson to William B. Giles (Dec. 26, 1825), reprinted in THE POLITICAL WRITINGS OF THOMAS JEFFERSON, supra note 24, at 169.

286. Letter from Abraham Lincoln to Committee of Boston Republicans (April 16, 1859), reprinted in THE POLITICAL THOUGHT OF ABRAHAM LINCOLN 123-24 (R. Current ed. 1967). 
taps, and that gives his federalism a certain veneer of inescapability.

The problem with Justice Rehnquist's federalism, however, is that of its parent, Jeffersonian republicanism. The tradition rests on unquestioned but questionable assumptions. Rehnquist (and Jefferson) assume that freedom means political autonomy. They conclude from this that the chief threat to freedom comes from a powerful central government. They assume that the state governments, being closer to the people, will be both competent and willing to guarantee the political and civil rights of their citizens. They further assume that whatever positive governmental action is necessary to "close the circle of our felicities" ${ }^{287}$ can be undertaken effectively by the states. ${ }^{288}$ Therefore, the Constitution is to be construed to limit severely the federal government's sphere of authority and thus reserve for the state governments, "the true barriers of our liberty in this country,"289 autonomous control over most domestic concerns. In order to fit the Civil War Amendments into this minimal federal scheme, Rehnquist views them as a mere perfection of the Jeffersonian axiom that all

287. Inaugural Address by President Jefferson (March 4, 1801), reprinted in D. MALONE, supra note 281 , at 22 .

288. That Jefferson should adopt these assumptions is understandable. His experience, both personal and cultural, was that powerful central governments were in practice the chief dangers to liberty. The Glorious Revolution of 1688 , the American Revolution, the republican struggle against Federalist persecution under the Alien and Sedition Acts, and the revolution by suffrage of 1800 all exemplified for Jefferson the political fact that strong governments tend toward despotism and must be reformed or overturned to preserve the rights of the people. See, e.g., Letter from Thomas Jefferson to James Madison (Dec. 20, 1787), reprinted in THE POLITICAL WRITINGS OF THOMAS JEFFERSON, supra note 24 , at $67-68$.

Later American history suggests that the state governments are not in fact the "barriers of liberty" Jefferson thought them to be. It was the states, for example; that played the active role in denying black citizens the rights Jefferson thought they were entitled to, see G. WILLS, INVENTING AMERICA 218-28, 306 (1978), and that were officially accorded them by the Civil War Amendments. Justice Rehnquist's adoption of Jefferson's presuppositions despite this later history points to a substantial difference between the two, despite rhetorical similarities. For Jefferson, the defense of state autonomy and opposition to federal power is always linked to the substantive goals of Jeffersonian republicanism. The most striking instance of Jefferson's federalism, his anonymous authorship of the Kentucky Resolutions of 1798, was a direct response to the passage by the Federalist Congress of the Alien and Sedition Acts, and their use by the Federalist administration of John Adams to harass republican editors and activists. Other significant statements by Jefferson on state autonomy were similarly linked to specific instances of the misuse of federal power. In office, Jefferson the Presidential statesman moved some distance in practice from the limited government rhetoric of Jefferson the political theorist and opposition politician. See A. SCHLESINGER, JR. THE AGE OF JACKSON 512 (1945). For Jefferson the republican, federalism was a tool with which to oppose the Federalist oligarchs, to be laid aside when inadequate for the proper end of government, "the cherishment of the people." Letter from Thomas Jefferson to Justice Johnson (1823), reprinted in THOMAS JEFFERSON ON DEMOCRACY, supra note 282 , at 45 .

By contrast, although Rehnquist occasionally mentions the instrumental value of federalism to American democracy, e.g., Community Communications Co. v. City of Boulder, 102 S. Ct. 835, 851 (1982) (Rehnquist, J., dissenting), his focus is almost always on the value of federalism in itself. What was for Jefferson a means to an end is for Rehnquist an end in itself.

289. Letter from Thomas Jefferson to Destutt de Tracy (Jan. 26, 1811), reprinted in THOMAs JEFFERSON ON DEMOCRACY, supra note 282 , at 52. 
citizens should possess equal rights vis-a-vis the government. ${ }^{290}$

Justice Rehnquist's repetition of the familiar Jeffersonian rhetoric tends to obscure the questionable nature of his claim that he is promoting the "intention of the Framers." The language of state sovereignty and the identification of a strong national government as the prime threat to liberty, belong more to the Constitution's original critics than to its Framers or supporters. ${ }^{293}$ The Anti-Federalists who opposed ratification of the 1787 document generally believed that a society can remain free only when it is geographically small, and its government can therefore retain close links with a homogeneous citizenry. ${ }^{292}$ Although most Anti-Federalists conceded the need to provide the Confederation government with a sure means of raising revenue and with expanded powers over international and interstate commerce, they were virtually unanimous in the "opinion that the leading feature of every amendment [of the Articles of Confederation] ought to be the preservation of the individual states in their uncontrolled constitutional rights." 293 They argued that it was "the states in their political capacity or as sovereignties"294 that ratified the Articles as "a firm league of friendship"295 and that therefore only the states could revise, dissolve, or replace the Articles with another compact.

Arguing against ratification in the Virginia Convention of June, 1788, Patrick Henry attacked the proposed Constitution as an attempt to replace the old, loosely knit confederation with "a great consolidated government." ${ }^{296}$ According to Henry, with the very first words of their proposal the Federalists had betrayed their reprehensible intent to bypass the states altogether and to fasten the new national government directly upon the individual:

What right had [the Framers] to say, "We, the people"? . . . Who authorized them to speak the language of "We, the people," instead of, "We, the states"? States are the characteristics and the soul of a confederation. . . .

... This [proposed] government will operate like an ambuscade.

290. G. WILLS, supra note 288 , at $225-28$.

291. See H. STORING, WHAT THE ANTI-FEDERALISTS WERE FOR 15 (1981).

292. See id. at $16-23$.

293. Letter from Robert Yates and John Lansing to Governor George Clinton (1787), reprinted in 3 THE ANNALS OF AMERICA 190 (1968). Yates and Lansing, both New York Delegates to the 1787 Convention, left Philadelphia when they realized the Convention was going to devise a new government.

294. Address by Luther Martin to Maryland legislature (Nov. 29, 1787), reprinted in 3 THE ANNALS OF AMERICA 166-67 (1968).

295. ART. CONFED. art. III.

296. Henry, Address to Virginia ratifying Convention (June 1788), quoted in 3 The Annals of America 281 (1968). 
It will destroy the state governments and swallow the liberties of the people, without giving previous notice. ${ }^{297}$

The Anti-Federalists' charge that the Constitution's Framers were motivated by hostility to the states' autonomy was not without cogency. The disorders of the 1780's had convinced men like James Madison that the "vices coming out of the state governments" were an even greater threat to American society than the weakness of the Confederation's government, and that a strong national government was the necessary remedy. ${ }^{298}$ Madison and the other Federalists went to the Constitutional Convention seeking " 'a due supremacy of the national authority' with 'the local authorities' left to exist only in 'so far as they can be subordinately useful., "299

The political necessities of compromise in the Gonvention and in the ensuing ratification struggles persuaded leading Federalist spokesmen to moderate their language and to present the Constitution as a unique combination of federal and national elements, with each coordinate government confined to, and protected within, its proper sphere. ${ }^{300}$ Nevertheless, to most contemporaries it was clear that the struggle over the Constitution was the final battle between the defendants of state sovereignty and the proponents of national supremacy:

[To the Anti-Federalist] [t]here is, it seems, finally no middle way between a federal or a consolidated government; and while he is willing to define a federal government as substantially more than a league, it is fundamentally a league. So, on the other side, while Publius is willing to define the American federal system as something less than a national government, it is for him fundamentally a national government. ${ }^{301}$

The idea of state sovereignty, which as we have seen is crucial to Justice Rehnquist's theory of federalism, was the subject of heated debate during the campaign for ratification of the Constitution. Unlike the Articles of Confederation, the Constitution contained no explicit guarantee of state sovereignty. Although the Constitution did provide equal representation for the states in one house of the federal legislature, and obviously

297. Id. at 281-82.

298. G. WOOD, supra note 23, at 467. "By 1787 Madison, like others, had become a thorough nationalist, intent on subordinating the states as far as possible to the sovereignty of the central govcrnment." Id. at 473.

299. Id. at 525 (quoting letter from James Madison to Edmund Randolph (April 8, 1787)).

300. Id. at 524-32.

301. H. STORING, supra note 282, at 37. "Publius" was the pseudonym used by Jay, Hamilton, and Madison in writing The Federalist Papers. 
assumed that the state governments would continue to exist, its opponents uniformly accused it of destroying state sovereignty. ${ }^{302}$

The Federalist response to this charge took two separate tacks. One was simply to deny that the states were or ever had been sovereign. Sovereignty, these Federalists asserted, had always belonged to the American people, as a whole. ${ }^{303}$ Other Federalists argued that the Constitution allowed the states a residual sovereignty. ${ }^{304}$ But this concession was probably more verbal than real. Federalists and Anti-Federalists agreed that the Articles of Confederation were based on the principle of state sovereignty. ${ }^{305}$ Because the Federalists claimed that "the existing Confederation is founded on principles which are fallacious," ${ }^{306}$ the Anti-Federalists concluded that the argument that the proposed Constitution preserved state sovereignty was mere propaganda. ${ }^{307}$ The validity of that conclusion is bolstered by the fact that both sides agreed that "two co-ordinate sovereignties would be a solecism in politics." ${ }^{2308}$ The Anti-Federalists wished to avoid such political bad grammar by denying sovereignty to the federal government. The Federalists, on the other hand, were united in their belief that the new Constitution would rid America of the "political monster" of autonomous state sovereignties within the Union. ${ }^{309}$

The nationalism that emerges with some clarity from the writings of the Constitution's supporters ${ }^{310}$ contrasts starkly with the loose federalism

302. Address by Thomas Tredwell to the New York ratifying convention (1788), quoted in A. MASON, The STATES RIGHTS DEBATE 70 (2d ed. 1972); Address by Patrick Henry to the Virginia ratifying convention (1788), quoted in A. MASON, supra, at 75; R. Yates, Letters of Brutus No. 15 , quoted in A. MASON, supra, at 112-13; L. MARTIN, THE GENUINE INFORMATION DELIVERED TO THE LEGISLATURE OF THE STATE OF MARYLAND (1787), quoted in A. MASON, supra, at 114; Address by Robert Whitehill to Pennsylvania ratifying convention (1787), quoted in A. MASON, supra, at 135.

303. Address by Archibald Maclaine to North Carolina ratifying convention (1788), quoted in A. MASON, supra note 302, at 165-66; Address by James Wilson to Pennsylvania ratifying convention (Dec. 6, 1787), quoted in A. MASON, supra note 302 , at 72 .

304. THE FEDERALIST No. 32, at 152 (Bantam Books ed. 1982) (A. Hamilton); id. No. 43, at 224 (J. Madison); id. No. 62, at 313-14 (Bantam Books ed. 1982) (J. Madison).

305. H. STORING, supra note 291 , at 9.

306. THE FEDERALIST No. 37, at 177 (Bantam Books ed. 1982) (J. Madison); cf. id. No. 42, at (Bantam Books ed. 1982) (J. Madison) ("[T]he articles of confederation have inconsiderately endeavored to accomplish impossibilities: to reconcile a partial sovereignty in the Union, with compleat sovereignty in the states....")

307. See A. MASON, supra note 302 , at 75 .

308. See Dissent of the Anti-Federalist Minority in the Pennsylvania ratifying convention (Dec. 18,1787 ), quoted in A. MASON, supra note 302, at 143; accord THE FEDERALIST No. 15, at 70 (Bantam Books ed. 1982) (A. Hamilton) ("the political monster of an imperium in imperio").

309. See G. WILLS, EXPLAINING AMERICA 164-75 (1981).

310. The Anti-Federalist attack on the Constitution was often summed up in the claim that it would result in a "consolidated government." See, e.g., Dissent of the Anti-Federalist Minority, supra note 302, at 142. It is significant that although the language of "consolidation" carried with it strongly nationalist overtones, see H. STORING, supra note 291, at 10-11, the cover letter over George Washington's signature sent with the proposed Constitution to the states spoke of "consolidation" as the object of the Convention's work: "In all our deliberations on this subject we kept steadily in our view, that which appears to us the greatest interest of every true American, the consolidation of our Union. ..." Quoted in G. WILLS, supra note 309, at 170. 
that Justice Rehnquist presents as the intention of the Framers. Rehnquist seems to have fallen into the curious historical error of projecting the language and thought of the opponents of the Constitution onto its drafters. This error leads him to misconstrue the instrument intended to fashion a strong central government as though it were the charter of state autonomy. The various Framers had differing goals to some extent, but they were unified in their opposition to the perpetuation of the model of an alliance of sovereignties that existed under the Articles of Confederation and that Rehnquist would recreate. ${ }^{311}$

Justice Rehnquist's "Framers" sound superficially like Jefferson, remarkably like the opponents of the Constitution, and not at all like the statesmen who created the Constitution and battled successfully for its ratification in the thirteen state conventions. His federalism, far from being "the intention of the Framers," is an inadvertent repudiation of part of their achievement. It would restore to the states, by judicial fiat, the "sovereignty, freedom and independence" that the Articles of Confederation guaranteed explicitly ${ }^{312}$ but that the Constitution replaced by an implicit assertion of the direct, unmediated relation of the new federal government to the American people as a unitary body politic. ${ }^{313}$

Therefore, Rehnquist's attempt to use the intention of the Framers as an objective basis for constitutional law fails at its most fundamental and crucial point-its connection to history. The power of his argument rests on the claim that his position is derived from objectively determinable historical facts about the Framers' purposes. But his reconstruction of the Framers' intention not only fails to convince, it in fact seems susceptible to objective refutation. ${ }^{314}$ The evidence is strong that the Framers intended to establish a vigorous national government for the purpose of securing the liberties of the sovereign people. Justice Rehnquist offers us instead an alliance of sovereign state governments dedicated to the preservation of their parochial autonomy. By so misreading the Constitution's text and history, Rehnquist commits the precise emotivist error that he set out to

311. Garry Wills has suggested that the success of "Publius" in disguising for tactical political reasons the Federalists' commitment to a strongly nationalist system of government has misled later readers of The Federalist Papers into reading it, and the Constitution it expounds, as defenses of a loose union of sovereign states, that is as federalist in Justice Rehnquist's sense. Wills argues, in accord with the position taken in this Article, that such a "federalist" reading misunderstands the Federalists' actual goals. See G. WILLS, supra note 309, at 172-75.

312. ART. CONFED. art. II.

313. U.S. CONST. preamble. Hamilton identified the inability of Congress under the Articles to act directly upon individuals as the Articles" "great and radical vice." THE FEDERALIST No. 15, at 70 (Bantam Books, ed. 1982) (A. Hamilton).

314. Indeed, some recent scholarship casts doubt on the claim that the states were sovereign even before the Constitution's ratification. See J. RAKOVE, THE BEGINNINGS OF NATIONAL POLITICS 13591 (1979); Morris, The Forging of the Union Reconsidered: A Historical Refutation of State Sovereignty over Seabeds, 74 COLUM. L. REV. 1057 (1974). 
avoid: the erection of a judge's personal values and opinions into constitutional norms. 